\title{
Conventional and additively manufactured stainless steels: A review
}

\author{
J. R. Jessy Michla ${ }^{\text {a }}$, N. Rajini ${ }^{\text {a, } *, \text { K. Senthilkumar }}{ }^{\text {b }}$, Suchart Siengchin ${ }^{\text {c }}$, \\ Sikiru Oluwarotimi Ismail ${ }^{\mathrm{d}}, \mathrm{T}_{\text {. Ram Prabhu }}{ }^{\mathrm{e}}$ \\ ${ }^{a}$ Department Mechanical Engineering, Kalasalingam Academy of Research and Education, \\ Srivilliputhur, India. \\ ${ }^{\mathrm{b}}$ Department of Mechanical Engineering, Kalasalingam Academy of Research and Education, \\ Krishnankoil-626126, Tamil Nadu, India. \\ ${ }^{\mathrm{c}}$ Department of Mechanical and Process Engineering, The Sirindhorn International Thai- \\ German Graduate School of Engineering (TGGS), King Mongkut's University of Technology \\ North Bangkok, 1518 Wongsawang Road, Bangsue, Bangkok 10800, Thailand. \\ ${ }^{\mathrm{d}}$ Department of Engineering, Centre for Engineering Research, School of Physics, Engineering \\ and Computer Science, University of Hertfordshire, AL10 9AB, England, United Kingdom. \\ ${ }^{e}$ CEMILAC, Defence R\&D Organization, Bangalore 560037, India.
}

*Corresponding author: N. Rajini, rajiniklu@gmail.com

\begin{abstract}
For the last three decades, enormous manufacturing processes have been widely employed in the field of transportation (aviation, automobile and marine) as well as various industrial sectors. Among the invented techniques, conventional manufacturing plays a versatile and cost effective role, but additive manufacturing (AM) possesses a more significant advantage of handling complicated parts or complex geometrical structures. The conventional processes were used from ancient times until the development of other advanced techniques. In recent development of technology, AM technology has shown a tremendous change in the manufacturing field. The process of development in AM began with polymers, then to composites and advanced to nanocomposites, continuously. AM provides a waste-free production management system with enhanced processes. Therefore, this detailed and compendious review describes the different stainless steels fabricated through conventional and AM techniques. It is evident that AM proves better than other several conventional techniques, by three dimensional (3D) printing of quality and complex stainless steels components that are impossible to manufacture through other methods. Notwithstanding, there still need of much efforts to improve AM technique by reducing the manufacturing cost, supporting mass production and printing large stainless steel components. With an increase in invention of various efficient state-of-the-art engineering software, robots in
\end{abstract}


manufacturing, artificial intelligence and smart manufacturing, the aforementioned drawbacks of AM technique/3D printing of various stainless steel structures will be soon eradicated.

Keywords: AM technique, conventional manufacturing, stainless steel, waste-free production, improved component.

\section{Introduction}

Stainless steels are being used in many applications: aerospace, marine, construction, chemical, petroleum and oil industries, among others. These alloys possess excellent in mechanical properties, including (i) high strength, (ii) hardness, (iii) impact strength, (iv) wear and (v) corrosion resistance. Besides, the stainless steels could behave well when they are subjected to high temperature for a longer period. There are three major categories of steels, namely:

(i) Austenitic stainless steels

(ii) Ferritic stainless steels

(iii) Martensitic stainless steels.

Amongst the three major classifications, the austenitic stainless steels are found to be used in most of the applications, followed by the ferritic and lastly, the martensitic. Martensitic stainless steels are used commonly for least applications. Besides, duplex steels possessed two-phase microstructure of austenite and ferrite steels. They have some attractive properties when compared with the counterpart materials, which are twice the strength of others. The ferrite austenitic duplex steels show complex precipitation as well as transformation changes, which would internally influence the mechanical and corrosive properties.

Three phases occur in the austenitic formation of the duplex steel. In the primary phase, segregation occurs by the austenitic elements that move forward to the eutectic rim as $\mathrm{L} \rightarrow \alpha+\gamma_{1}$. Then, the solid state transformation occurs and forms a ferrite state $\left(\alpha \rightarrow \gamma_{2}\right)$ in the secondary phase. In the tertiary phase, the transformation of ferrite changes to a eutectoid state $\left(\alpha \rightarrow \gamma_{3}+\sigma\right)[1]$.

\subsection{Austenitic stainless steels}

Austenitic stainless steel comprises of 16 to $26 \%$ of chromium and 2 to $20 \%$ of nickel, which are helped to provide: (i) better formability, (ii) increased corrosion and (iii) wear resistance. This grade is a non-magnetic metal and cannot be hardened by heat treatment. The austenitic steels are widely used in offshore applications. They exhibit a great strength, resistance to corrosion and erosion environment, due to the presence of high number of alloying elements. The wide 
applications of austenitic stainless steel include: (i) food and beverage industries, (ii) tins, (iii) automotive rim, (iv) medical instruments and (v) structural parts for harsh environments. The chemical compositions of various stainless steels are presented in Table 1 [2].

Table 1

Chemical compositions of various stainless steels [2].

\begin{tabular}{|c|c|c|c|c|c|c|c|c|c|c|}
\hline \multirow{2}{*}{$\begin{array}{l}\text { Details of the } \\
\text { elements }\end{array}$} & \multicolumn{10}{|c|}{ Steel designation } \\
\hline & 201 & 301 & 304 & $304 \mathrm{~L}$ & 305 & 309 & $309 S$ & 316 & $316 \mathrm{~L}$ & $17-4 \mathrm{PH}$ \\
\hline Carbon (C) & 0.15 & 0.15 & 0.08 & 0.03 & 0.12 & 0.2 & 0.08 & 0.08 & 0.03 & 0.07 \\
\hline $\begin{array}{l}\text { Manganese } \\
(\mathrm{Mn})\end{array}$ & $\begin{array}{l}5.50- \\
7.50\end{array}$ & 2 & 2 & 2 & 2 & 2 & 2 & 2 & 2 & 1 \\
\hline $\begin{array}{l}\text { Phosphorus } \\
\text { (P) }\end{array}$ & 0.06 & 0.045 & 0.045 & 0.045 & 0.045 & 0.045 & 0.045 & 0.045 & 0.045 & 0.04 \\
\hline Sulfur (S) & 0.03 & 0.03 & 0.03 & 0.03 & 0.03 & 0.03 & 0.03 & 0.03 & 0.03 & 0.03 \\
\hline Silicon $(\mathrm{Si})$ & 1.0 & 0.75 & 0.75 & 0.75 & 1.0 & 0.75 & 0.75 & 0.75 & 0.75 & 1 \\
\hline $\begin{array}{l}\text { Chromium } \\
(\mathrm{Cr})\end{array}$ & $\begin{array}{l}16- \\
18\end{array}$ & $\begin{array}{l}16- \\
18\end{array}$ & $\begin{array}{l}18- \\
20\end{array}$ & $\begin{array}{l}18- \\
20\end{array}$ & $\begin{array}{l}17- \\
19\end{array}$ & $\begin{array}{l}22- \\
24\end{array}$ & $\begin{array}{l}22- \\
24\end{array}$ & $\begin{array}{l}16- \\
18\end{array}$ & $\begin{array}{l}16- \\
18\end{array}$ & $15-17.5$ \\
\hline Nickel (Ni) & $\begin{array}{l}3.5- \\
5.5\end{array}$ & $6-8$ & $8-12$ & $8-12$ & $\begin{array}{l}10- \\
13\end{array}$ & $\begin{array}{l}12- \\
15\end{array}$ & $\begin{array}{l}12- \\
15\end{array}$ & $\begin{array}{l}10- \\
14\end{array}$ & $\begin{array}{l}10- \\
14\end{array}$ & $3-5$ \\
\hline Nitrogen $(\mathrm{N})$ & 0.25 & 0.10 & 0.10 & 0.10 & - & - & - & 0.10 & 0.10 & - \\
\hline $\begin{array}{l}\text { Molybdenum } \\
\text { (Mo) }\end{array}$ & - & - & - & - & - & - & - & $2-3$ & $2-3$ & - \\
\hline $\begin{array}{l}\text { Columbian } \\
\text { +Tantalum }\end{array}$ & - & - & - & - & - & - & - & - & - & $0.15-0.45$ \\
\hline Copper $(\mathrm{Cu})$ & - & - & - & - & - & - & - & - & - & $3-5$ \\
\hline
\end{tabular}

Iron (Fe) The iron content occupies the balancing percentage of elements in the stainless steel 
Ferritic stainless steel comprises of about $12 \%$ of chromium. The different grades of the ferritic stainless steel include 409, 430, 430L, 434, 444, 442, to mention but a few. Similar to austenitic stainless steel, ferritic stainless steel cannot be hardened by heat treatment process. However, they are hardened by cold working. The grain structures of ferritic steels are of bodycentered cubic (BCC) lattice, whereas the austenitic steel has a face-centered cubic structure (FCC). The austenitic steels show a susceptible effect on stress cracking, whereas the ferritic steels show a better resistance against the stress cracking behavior. The composition of carbon in ferritic stainless steel is about $0.03 \%$; hence they exhibit average ductility and low coefficient of thermal expansion. They possess good thermal related properties, therefore they could be used for hightemperature based applications: boilers and heat exchangers. Besides, the ferritic steels exhibit better oxidation resistance and good corrosive resistance properties. Table 2 depicts important mechanical properties of ferritic stainless-steel material.

\section{Table 2}

Mechanical properties of ferritic stainless steel [3,4].

\begin{tabular}{lcccc}
\hline Steel alloys & $\begin{array}{c}0.2 \% \text { of yield } \\
\text { strength }(\mathrm{MPa})\end{array}$ & $\begin{array}{c}\text { Ultimate tensile } \\
\text { strength }(\mathrm{MPa})\end{array}$ & $\begin{array}{c}\text { Elongation to } \\
\text { fracture }(\%)\end{array}$ & $\begin{array}{c}\text { Strain hardening } \\
\text { coefficient }\end{array}$ \\
\hline $\begin{array}{l}\text { 0.15\%C } \\
\text { carbon steel }\end{array}$ & 285 & 385 & 37 & 0.2 \\
409 & 275 & 470 & 30 & 0.18 \\
430 & 345 & 515 & 25 & $0.18-0.22$ \\
$\mathrm{Fe}-29 \%, \mathrm{Cr}-$ & 400 & 550 & 20 & 0.2 \\
$4 \%, \mathrm{Mo}-2 \% \mathrm{Ni}$ & & 620 & 70 & $0.30-0.50$ \\
304 & 255 & & & \\
\hline
\end{tabular}

\subsection{Martensitic stainless steels}

The martensitic stainless steels can be of higher or lower carbon steels which are made using the composition of iron with $12-17 \%$ of chromium and carbon of $0.10-1.20 \%$. When these steels are used for fabricate pumps, valves and shafts, the content of carbon elements are obtained to be nearly $0.4 \%$. When the carbon content exceeds $0.4 \%$, they are primarily relevant for wear resistance-based applications. For instance: (i) plastic injection molds (ii) cutlery surgical blades and (iii) nozzles. 
The martensitic stainless steels sometimes comprise of nickel (Ni), which would allow for higher content of chromium ( $\mathrm{Cr}$ ) and/or molybdenum (Mo), thus they enhance corrosion resistance property. Toughness is also found to be improved when they comprise the lower content of carbon elements. When the stainless steel comprises of lower carbon, $13 \%$ of $\mathrm{Cr}$ and $4 \%$ of $\mathrm{Ni}$, they would offer excellent mechanical properties, good weldability and good resistance against cavitation. Therefore, they are preferred for nearly all types of hydroelectric turbines around the world. For instance, they are utilised at 'Three Gorges' dam in China. Further addition of boron (B), cobalt (Co) and titanium (Ti) help to enhance the high temperature-based properties; to improve a creep resistance [5].

Regarding the fabrication process, conventionally processed metal alloys give a great potential for mass production. The parts are of equiaxed grain structure and homogeneity on defined boundaries. These conventional techniques followed more common procedure in the past decades. However, nowadays, additive manufacturing (AM) techniques overcome the conventional technique by their advantages. The AM technique is identified as a modern technique which gives a breakthrough performance and unparalleled flexibility that gained more interest amongst the researchers owing to their (i) deposition rate, (ii) material savings, (iii) adaptability as well as (iv) low energy consumption [6]. Moving forward, this present paper subsequently discusses various fabrication techniques of stainless steels under conventional and AM processes with respect to the property variation and heat treatment.

\section{Conventional manufacturing techniques}

In conventional manufacturing technique, the objects are fabricated by employing (i) casting process, (ii) forging process and (iii) powder metallurgical process, to mention but a few. In these approaches, the unwanted parts are needed to be removed once the fabrication processes are over. For removal of the unwanted parts, special tools are mandatory. Though, a lot of manufacturing techniques are existing to produce the stainless steels, there are three significant methods that are often considered based on their usages. The major three techniques include: (i) metal injection molding (MIM), (ii) casting and (iii) sintering. Nevertheless, these techniques have some demerits when compared to the AM; with a lower production cost. Besides, AM could fabricate high precision as well as a low complexity in manufacturing.

\subsection{Metal injection molding}


Metal injection molding (MIM) plays a remarkable role in the manufacturing of metals and ceramics, due to their precise and mass production. This manufacturing technique consumes lesser material, but the products are of high density. Fig. 1 illustrates the step-by-step procedure of producing the finished products, using the MIM technique. The MIM process starts with the feedstock preparation done by homogeneous mixing of powder and binder particles [7]. The powders are classified based on their characteristics, sizes and morphologies. Furthermore, the homogeneous mixture of powder and binding materials are fed through the injection molding chamber, followed by the debinding. The debinding process handled by considering the binding time and the composition of binders. The debinding could be carried out by either employing (i) catalytic debinding, (ii) solvent debinding or (iii) thermal debinding; the debinding types are chosen based on the powder and binder types.

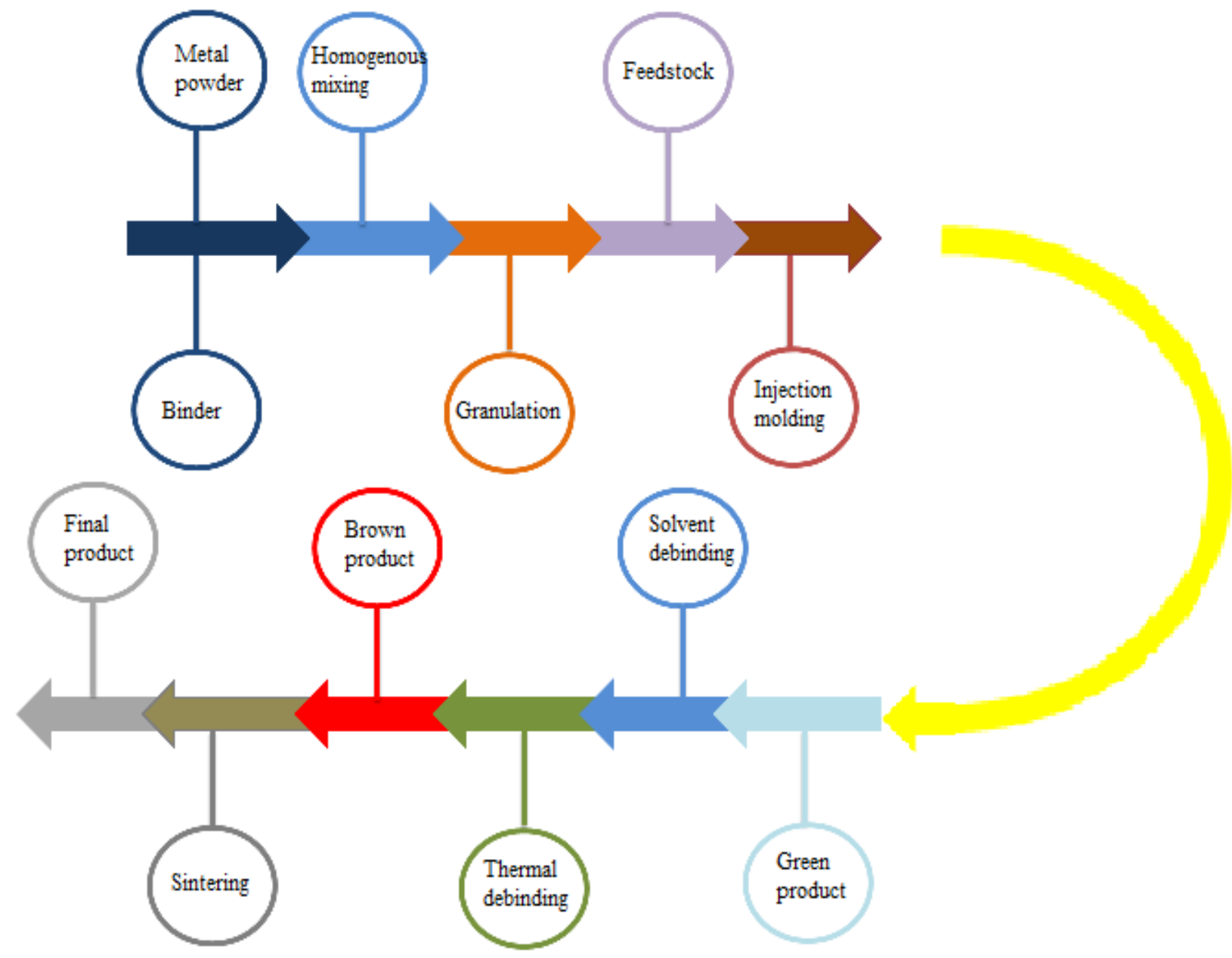

Fig.1. Metal injection molding process.

The sintering temperature and heat treatment of steels could be controlled in order to enhance the mechanical properties without influencing the corrosion resistance of the alloy $[8,9]$. Usually, 
sintering process manipulates the martensitic phase by providing good microstructure on maintaining the micro particles in the form of spherical oxides or carbides $[10,11]$. The sintering temperature of stainless steel usually ranges between 1200 to $1350{ }^{\circ} \mathrm{C}$ and the sintered time between 20 and 60 minutes. The temperature should be controlled as well as remains above the solidus temperature for preventing the distortion in the size of the sintered product [12]. The fabrication of $17-4 \mathrm{PH}$ steel and $316 \mathrm{~L}$ of austenitic stainless steel are discussed in the current section; whereby the above said designated steels are made by using the MIM technique. In MIM, metal powders are mixed with the binding agents (wax and polypropylene) in a mixing chamber. The mixture is granulated into a fine powder and the feedstock is subjected into the injection molding machine in the form of liquid. Under pressure and heat, the raw product is obtained. The raw material is subjected to a thermal binding cleaning to form a brittle green product. Once after sintering, pores are eliminated and formed as a dense solid finished product.

Moreover, the mechanical properties of 17-4PH stainless steel is improved by the addition of 1 wt.\% of nickel boron $(\mathrm{NiB})$ and it is further improved by heat treatment process [13]. At low feedstock loading and particle size of around $45 \mu \mathrm{m}$, the mechanical properties of 17-4PH stainless steel is greatly improved [14]. On fabricating multiple cavity mold, the accumulation of powder leads to the segregation of the fabricated component. This can be rectified by the spatial distribution of powdered particles during fabrication [15]. On corrosion test of 17-4PH steel under phosphate buffer solution, pitting corrosion is slightly higher than other conventional techniques. This is attributed to a low amount of Co present in the metal [16].

When 316L steel powder and iron $(\mathrm{Fe})$ powder fused along with $17-4 \mathrm{Ph}$ steel powder separately on micro-metal injection molding, there is an evidence of a finite change in porosity and magnetic properties, which actually depend on sintering temperature and this needs to be controlled. Also, higher tolerance can be achieved by reducing the border dimension [17]. The binder particle is added with the injection molding powder, which actually binds the particle to each other during fabrication and provides a well-defined output [18]. Soft tooling is used for a low production runs as low molding pressure and temperature is generally required for injection molding process. Ceramics and metal alloy injection molding process combine several machined or cast components into one cost-effective product, which leads to the elimination of several manufacturing steps $[19,20]$. $316 \mathrm{~L}$ powder is water-atomized before pouring the powder into the injection mold chamber, which in turn results to improved ductility and corrosion resistance components. Also, this powder is doped with graphite at required parts per million, around 1000 ppm to avoid pitting corrosion. But, excessive addition of graphite leads to excessive carbon on the surface of the sintered component [21]. In MIM, very fine powders such as nano-scale powders 
are used as a feedstock material [22]. Low viscous feedstock provides a homogeneous distribution of powder [23,24]. This actually reduces the linear shrinkage of produced material [25]. Therefore, powder injection molding depends greatly on the feedstock composition, temperature gradient and powder particle size.

\subsection{Casting techniques}

The casting process is carried out by pouring the molten metal into the cavity of the designed mold, followed by hardening of molten metal. Once the solidification process is completed, the part is subjected to finishing treatment; whereby the object is obtained in the desired shape with surface finish [26].

In the current section, investment casting and continuous casting of stainless steel are elucidated [27,28]. The investment casting is an ancient process, whereby the wax pattern coated with refractory ceramic material is used. The most commonly used metals include: (i) aluminium, (ii) bronze, (iii) stainless steel, (iv) magnesium and (v) carbon steels. The finished products are subjected to grinding or sandblasting to smooth the surface as well as to remove the imperfections. The investment casting technique is the best suited for massive production, whereby the increased time and labor cost are eliminated [29,30]. Fig. 2 shows the step-by-step procedure of investment casting technique.
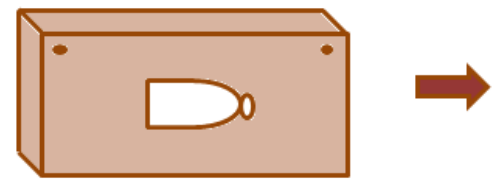

Wax pattern prepared through Injection molding

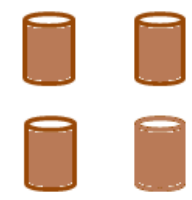

Separate the casted component

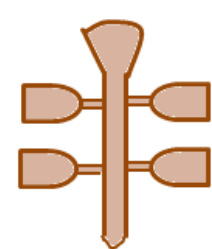

Assembly of patterns attached to sprue

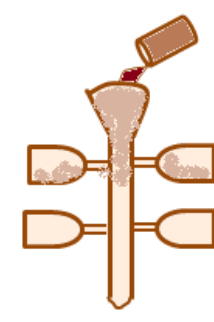

Pouring of molten metal into the mold
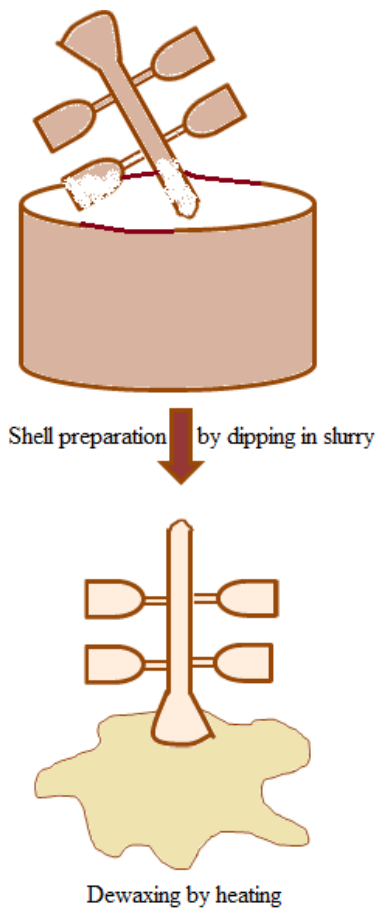

Fig. 2. Schematic representation of the investment casting process [31]. 
In order to prevent the reaction between the stainless steel surface and the environment, either of alloying process or coating process is preferred. Application of in-situ coating of aluminium (Al) on the surface of stainless steel enhances the hardness as well as a magnetic hysteresis loop is formed [32]. In the case of a low carbon steel, continuous or strip casting approach is followed. The sheets or strips are directly cast from the molten metal, followed by the cooling without hot rolling process.

In addition, formation of delta ferrite ( $\delta$-ferrite) in the continuous casting affects the high temperature, workability and the corrosion resistance. When steel is heated above its critical temperature, a FCC structured austenite is formed. The austenite phase contains $2.03 \%$ of carbon, which strengthens the material and hardens on further heat treatment process. This heat treatment process converts the austenite phase into cementite, pearlite, bainite and/or their combinations. The cementite is converted into $\delta$-ferrite by diffusion of carbon atoms during transformation [33]. Ferrite is stronger than austenite. Therefore, it forms a primary strengthening support to the material. The next strength supporting agent is chromium, nickel and iron contents. On transformation phase $\sigma$ solid phase has to be avoided, due to its brittle nature [34]. The common problem associated with casting processes include, but are not limited to: (i) porosity, (ii) shrinkages, (iii) embrittlement and (iv) mismatch of mold attachments. The effects of these challenges are minimized by enhancing the mechanical properties of stainless steel. Thus, the gating valve system helps to reduce the adverse effects and inclusion of vent holes releases the air pressure inside the mold cavity $[35,36]$.

In the investment casting technique, the shrinkage occurs by varying the pouring techniques and solidification range. These problems are rectified by varying the process parameters, such as: (i) feed rate, (ii) shell mold temperature and (iii) increased solidification time. The microstructural evaluation is done by introducing a novel approach called 'cellular algorithm' (CA), whereas the nucleation and the grain growth are simulated. Besides, the CA offers a good correlation between the microstructure of $17-4 \mathrm{PH}$ cast materials and their simulated model [37]. In the investment casting technique, the casting temperature and mold thickness yield a great impact on fluidity. However, the increased pouring temperature would produce more shrinkage related problems regardless of the filling system [38]. The existence of shrinkage during the casting process of 174PH alloy deteriorates its mechanical properties, which include yield strength, ultimate tensile strength and hardness. Though, H1100 provides a better property than the H925, necking and strain failures occur during the heat treatment process. Thus, the $\mathrm{H} 1100$ is not preferred to $17-4 \mathrm{PH}$ stainless steel $[39,40]$. 
Also, the casting layout of SUS310 steel can be analyzed using computer-aided engineering (CAE) approach. This approach helps to increase the product development as well as reducing the time consumption and overall cost [41]. In aircraft engines, the steel turbine blades are made up of SCH12 material. A retained melt modulus (RMM) model helps to examine the gating system schemes and predict the defect that occurs over the area of the melt flow. This model normally helps to produce a quality output with minimal cost products $[42,43]$. In nuclear power plant, $304 \mathrm{~L}$ steel pipe is used in coolant system; whereby the pipes manage or withstand the temperature range of 290 to $330{ }^{\circ} \mathrm{C}$. In investment casting technique, by increasing the aging time of casting, the elongation percentage reduces with an increase in mechanical properties [44].

The crack growth initiation is based on the stress intensity factor. Besides that, the aging time improves the mechanical properties of the material $[45,46]$. Duplex stainless steel is used as pipe materials and water reactors that operate in high-temperature circumstances. As thermal aging time increases, an enormous increase in the hardness and elongation of ferrite steel is observed. As the aging time is set to 10,000 hours, it exhibits good mechanical strength [47]. Summarily, some important mechanical properties of different types of stainless steel materials are listed in Table 3 .

\section{Table 3}

Mechanical properties of different types of stainless steel materials.

\begin{tabular}{lcccc}
\hline Classifications based on casting & $\begin{array}{c}\text { Tensile strength } \\
(\mathrm{MPa})\end{array}$ & $\begin{array}{c}\text { Yield strength } \\
(\mathrm{MPa})\end{array}$ & $\begin{array}{c}\text { Elongation } \\
(\%)\end{array}$ & $\begin{array}{c}\text { Hardness } \\
(\mathrm{HV})\end{array}$ \\
\hline 316L [48] & 450 & 200 & 69 & 160 \\
Duplex stainless steel [49] & 762 & 356 & 14 & 217 \\
CF8M-Duplex steel [50] & 525 & 318 & 68.6 & 300 \\
CA-6NM steel [51] & 826 & 688 & 24 & 271 \\
\hline
\end{tabular}

A three-point bending test is performed by using Gurson's modeling approach on CF8M steel to find out the shrinkage cavities. Finite element method (FEM) is also used to predict the shrinkage cavities on duplex steel material, which helps in the safety assessment of the cast components [52]. Besides, the surface properties are examined using the FEM approach, whereby the steel is subjected to the heat treatment process. It is evident through the scanning electron microscope (SEM) analysis that quenching and tempering processes produce fractured surfaces, cavities and hot tears on the steel alloy [53].

In centrifugal casting of martensitic stainless steel, the cracks were protruded from the internal surface to the external surface through inter-granular mode. By analysis through FEM of 
thermoelastic-plastic model, the thermal history is studied. It shows that the crack length exceeds up to $40 \mathrm{~mm}$ length in its path [54]. Equiaxed grains exhibits a weak and random surface, and the columnar grains possess a strong bonding throughout the thickness due to heterogeneous nucleation and grain growth [55]. High grade stainless steel alloys such as $18 \mathrm{Cr}-10 \mathrm{Ni}-2 \mathrm{Mo}$ or AISI 316L or a super alloy, nickel-base alloys, such as Inconel or Hastelloy, among others are more reliable under the condition of high temperature and stress conditions [56]. When comparing 316L stainless steel with structural 30CrNiMo8 steel alloy, the mechanical properties of stainless steel is better than that of structural steel [57].

\subsection{Sintering techniques}

The sintering technique is a kind of powder metallurgical process, which helps to produce a component of fine grain structure and excellent mechanical properties. Besides, this process prevents void formation. However, the diffusion rate increases owing to the machining processes. For instance, the 17-4PH steel is fabricated through the powder metallurgical technique (Fig. 3), which possesses higher strength and ductility [58]. During the sintering process, the temperature plays a significant role. For instance, $316 \mathrm{~L}$ is fabricated at a temperature of $1300{ }^{\circ} \mathrm{C}$, whereby the mechanical properties of $316 \mathrm{~L}$ are enhanced [59]. The hardness of $316 \mathrm{~L}$ is depended on the grain size of the particle. Furthermore, it is observed that the enhanced microstructure and functional properties during the sintering process are obtained by using boron nitride sprays along with the graphite foils rather than using graphite foils [60].

The austenitic steel is prepared by sintering process using the steel powder along with other compounds: $1 \mathrm{wt} . \%$ of yttria and $0.6 \mathrm{wt} . \%$ of boron. The boron content helps in oxidation resistance by the formation of eutectic borides, while the yttria increases the oxidation resistance by reducing porosity defect. When comparing the performance of oxide formation between yttria and boron, the later performs better than the former [61]. Spark plasma sintering is employed to fabricate the $316 \mathrm{~L}$ steel, using silicon nitride and yttria. This results to an improved mechanical properties and enhancement in the distribution of grains, as observed by SEM [62]. 


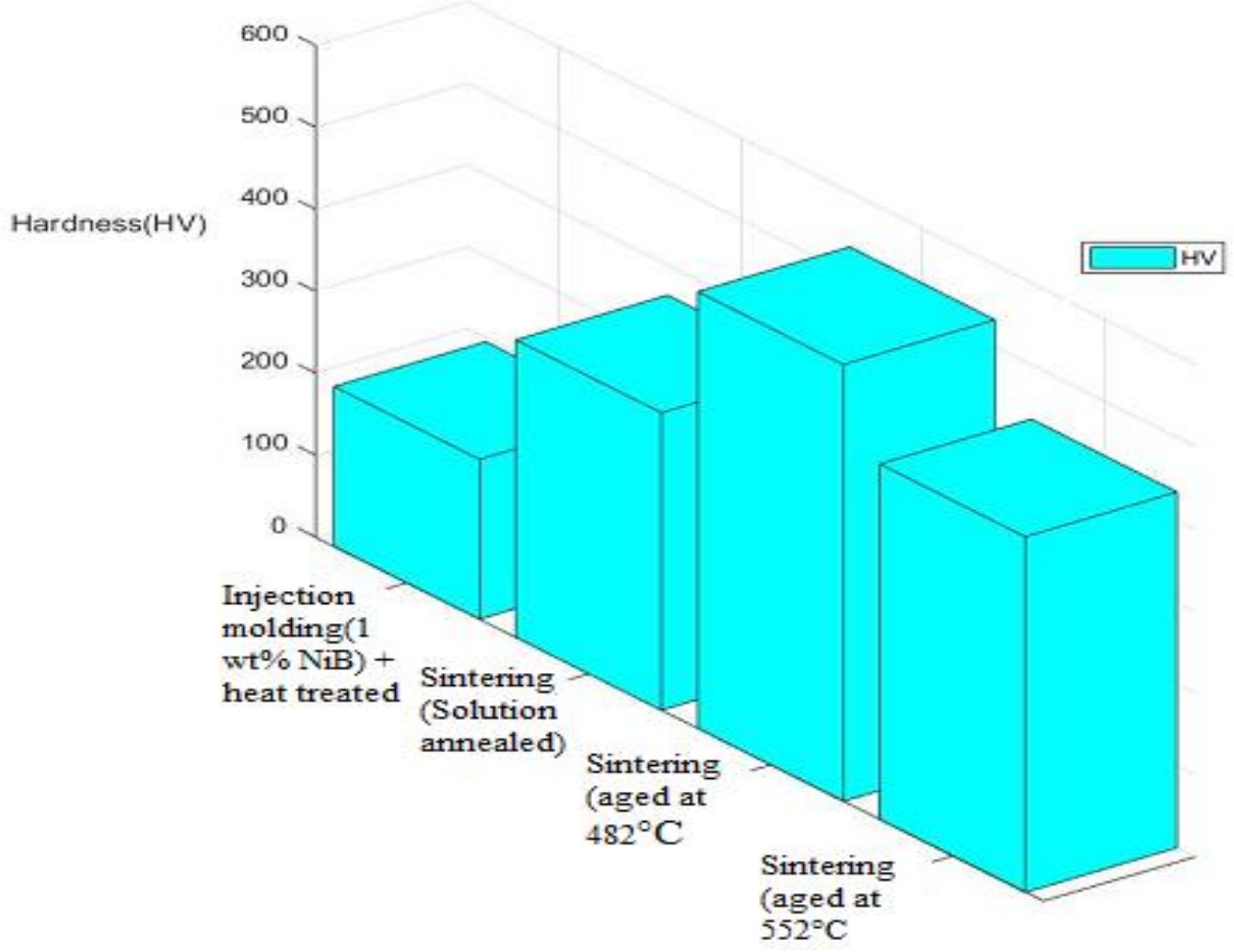

Fig. 3. Hardness value of $17-4 \mathrm{PH}$ steel on the various heat treatment processes $[13,14,16,18,57]$.

Moving forward, in another study carried out, the sintering technique is used to fabricate the 316L steel alloy, whereby the borides are varied by using different wt.\% ranged between 0.6 and 0.8. The mechanical properties of these alloys are enhanced as the inter-granular structure of borides are found to improved. The formation of transfer layer acts as a barrier against the wear, whereby the transfer layer is formed during the oxidation of borides [63]. Usually, nitriding of $316 \mathrm{~L}$ is preferred for mechanical strength as well as against the corrosion resistance of components. Besides, the micro-abrasive wear is decreased by nitriding. The properties of metal are improved by the addition of yttria during the fabrication of steel [64]. When 316L is sintered in the atmosphere of hydrogen or in a vacuum condition, the corrosion rate and the porosity decrease. These components are helpful in the field of medicine for surgical instruments [65]. The austenitic 316L exhibits a better performance when the temperature is maintained between 1200 to $1400{ }^{\circ} \mathrm{C}$, and the mechanical properties are enhanced [66]. In another work, density, hardness and tribological properties of 316L steel increase by the addition $\mathrm{Cu}-10 \mathrm{Sn}$ alloy. The maximum relative density is achieved with addition of 25 vol. $\%$ of additives, during sintering process [50].

When comparing the corrosion resistance of $304 \mathrm{~L}$ and $316 \mathrm{~L}$ stainless steels, using fabrication techniques such as sheet metal process and sintering, the former exhibits better performance. In the case of sintering process, pitting occurs; resulting to a worse corrosion performance. Besides, 
the 304L exhibits a better corrosion resistance than the 316L counterpart in the sodium chloride $(\mathrm{NaCl})$ atmosphere [67]. The corrosion resistance of 304L stainless steel increases with an addition of $\mathrm{TiN}$ when it is subjected to $3.5 \mathrm{wt} . \%$ of $\mathrm{NaCl}$ solution [49].

Additionally, a novel technique called 'spark plasma sintering' is used to fabricate the gas nitride austenite stainless steel. The sintered component with nitride powder exhibits better mechanical properties and corrosion resistance. The strengths are comparable to high-speed steels or high entropy alloys, whereas the toughness remains higher value of 68 . On addition of chromium nitride along with stainless steel powder, the microstructural analysis shows an homogeneity in the distribution of these materials in the specimen. Since the chromium nitride increases, both micro-hardness and mechanical strength are enhanced [69]. The austenitic stainless steels are prepared by using powder metallurgy approach. They exhibit better (i) mechanical, (ii) surface properties and (iii) paramagnetic behaviors. Besides, these steels show phase transformations, when they are deformed by mechanical, heat treatment and magnet processes [70]. Table 4 shows various mechanical properties of 316L stainless steel under different types of fabrication processes.

\section{Table 4}

Mechanical properties of 316L stainless steel under various fabrication processes [59-61, 71- 75].

\begin{tabular}{|c|c|c|c|c|c|}
\hline $\begin{array}{l}\text { Different } \\
\text { manufacturing } \\
\text { techniques }\end{array}$ & Condition & $\begin{array}{c}\text { Ultimate } \\
\text { tensile strength } \\
(\mathrm{MPa})\end{array}$ & $\begin{array}{c}\text { Yield } \\
\text { strength } \\
(\mathrm{MPa})\end{array}$ & $\begin{array}{l}\text { Elongation } \\
\text { at break }(\%)\end{array}$ & $\begin{array}{c}\text { Hardness } \\
\text { (HV) }\end{array}$ \\
\hline Wrought & - & 483 & 172 & 30 & 220 \\
\hline Wrought & Heat treated & $505-578$ & $222-265$ & $76-81$ & 155 \\
\hline Casting & $\begin{array}{l}\text { Gas atomised } \\
\text { powder }\end{array}$ & 518 & 255 & 35 & 220 \\
\hline $\begin{array}{l}\text { Continuous } \\
\text { casting }\end{array}$ & - & 1364 & - & 7 & 471 \\
\hline $\begin{array}{l}\text { Shell mould } \\
\text { casting }\end{array}$ & - & 1040 & 1260 & 9 & $350-480$ \\
\hline Forging & $\begin{array}{l}\text { Gas atomised } \\
\text { powder }\end{array}$ & 627 & 290 & 55 & 220 \\
\hline
\end{tabular}




\begin{tabular}{|c|c|c|c|c|c|}
\hline $\begin{array}{l}\text { Metal injection } \\
\text { moulding }\end{array}$ & $\begin{array}{l}\text { Water } \\
\text { atomised } \\
\text { powder }\end{array}$ & 548 & 203 & 57 & 286 \\
\hline $\begin{array}{l}\text { Spark plasma } \\
\text { sintering }\end{array}$ & - & 315 & 275 & - & 345 \\
\hline Sintering & - & 431 & 207 & 23 & 127 \\
\hline Sintering & With $\mathrm{MoSi}_{2}$ & $486 \pm 15$ & - & $22 \pm 2$ & 146 \\
\hline Sintering & $\begin{array}{l}\text { With nitrogen } \\
\text { addition }\end{array}$ & 600 & 420 & 14 & 137 \\
\hline $\begin{array}{l}\text { Electron beam } \\
\text { melting AM }\end{array}$ & - & 509 & 253 & 59 & 165 \\
\hline $\begin{array}{l}\text { Electron beam } \\
\text { melting }\end{array}$ & - & 509 & 253 & 59 & 165 \\
\hline $\begin{array}{l}\text { Hot isostatic } \\
\text { pressing }\end{array}$ & - & $450-570$ & $160-220$ & $42-54$ & - \\
\hline DMLS & & 518 & 288 & 47.4 & 235 \\
\hline $\begin{array}{l}\text { Gas metal arc } \\
\text { AM }\end{array}$ & & $533 \pm 23$ & $236 \pm 6$ & $64 \pm 5$ & 200 \\
\hline
\end{tabular}

\section{Additive manufacturing techniques}

With fabrication of components through the traditional means, the finished product requires machining, carving and shaping. The AM parts show perfect shapes without much postmanufacturing processes in the final desired products. In the case of aero-engines, the AM has a potential of processing at high temperatures. For instance, the National Aeronautics and Space Administration (NASA) engineers have designed and manufactured a metal rocket injector through AM, using Ni-Cr alloy powder. The rocket injector is made without any joints, thus it saves time and material cost [76]. The advantages of AM include: (i) design freedom, (ii) lightweight structure scan is possible to fabricate by using lattice designs, (iii) complex internal channels such as honeycomb structures with micron-size holes and (iv) several parts are built-in one process. The consumption of raw materials is 25 times lesser than the conventional machining process. Short term production is possible, that is, complex parts are produced in a few hours with application of AM technique, including the post-processing treatment.

It is reported that around $35 \%$ of research works have been published using steels, when compared to other metals. This shows that the next stage of development of metals is through AM. 
The process development of AM initialized from polymers, then to composites, nanocomposites, and then to metal alloys, among other materials.

More also, in the case of AM, the laser radiation selectively melts the binder particles, and the liquid metal is poured into it and finally solidified by cooling. The factors which are taken into consideration for the choice of AM technique are thermal cracking and porosity [77,78]. The design and computational calculations are done using the MATLAB tool. The graded complexshaped objects are fabricated through three dimensional (3D) printing in a highly economical and infiltrated orientation profile [79]. Moreover, any complex geometry patterns can be created. Printed electrical circuitries embedded with Al matrices can be fabricated through advanced technology, such as ultrasonic AM. This method exhibits an improvement in the integrity and mechanical performance of the multi-functional composites [80]. The post-processing heat treatment produces an excellent surface finish. However, this approach is time-consuming and expensive process [81]. The mechanical properties are further improved by post heat treatment process after manufacturing. The grains are equally distributed, and the heat treatment improves the hardness, yield strength, tensile strength and percentage of elongation. By controlling the process parameters, the overall performance of the process is controlled [82]. Even though, there are several advantages such as high resolution, internal passages, among others [51], the difficulties of printing techniques are high reflectivity of material and porosity caused due to the thermal conductivity [83]. Another drawback is that oxidation occurs during the solidification of metal in the air. This risk can be controlled by employing inert gases, such as argon and nitrogen gases, to prevent the oxidation while on the atomization process.

Similarly, the non-melted powders used in the manufacturing process are sieved and reused to reduce the material wastage and support the green environment [51]. The parameters optimization (especially density) can be done through the Taguchi's method, and the results are analyzed through signal-to-signal noise $(\mathrm{S} / \mathrm{N})$ ratio and analysis of variance (ANOVA) methods [84]. The parameters, such as energy from the laser, scanning speed, the feed rate of powder and flow rate of shielding gas [85] under design freedom [86] affect experimentally on fabrication, as observed. Fig. 4 summarily shows the major types of metal AM. In the present study, both powder bed technology and wire arc AM are extensively and subsequently elucidated. 


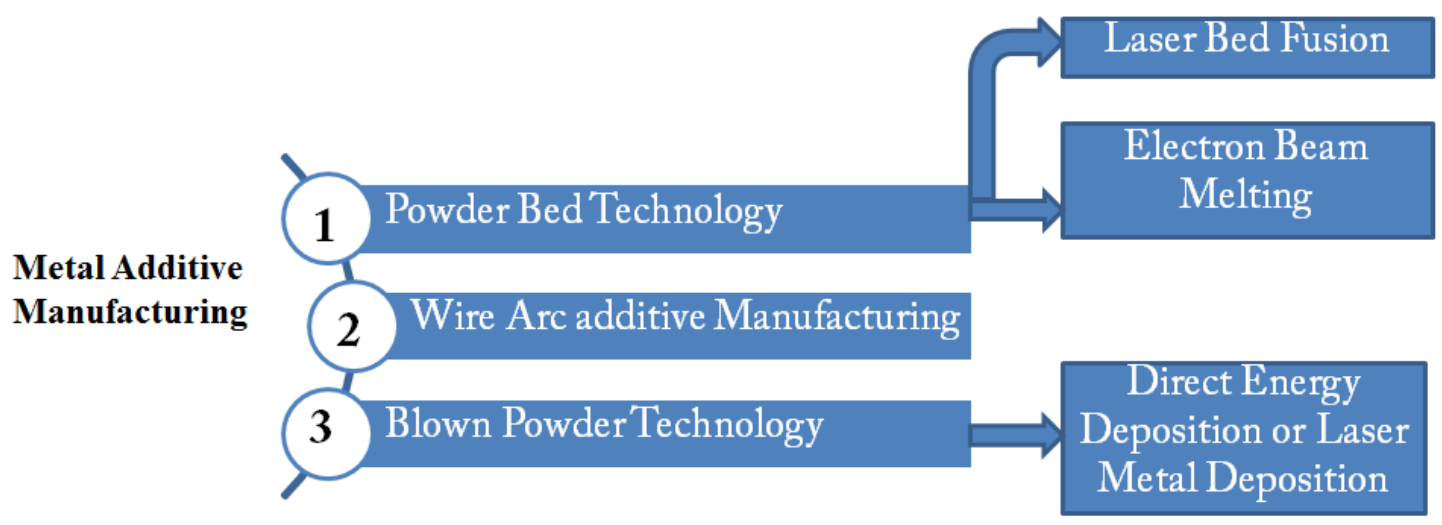

Fig. 4. Classifications of metal AM.

\subsection{Wire arc additive manufacturing}

Out of many manufacturing techniques, the wire arc additive manufacturing (WAAM) is identified as a modern technique (Fig. 5). WAAM gives breakthrough performance and unparalleled flexibility that gains wide interest among the researchers, because of its advantages: (i) cost-effectiveness, (ii) high energy efficiencies, (iii) deposition rate, (iv) material saving, (v) adaptability and (vi) low energy consumption. Thus, the large-scale structural components could be fabricated in a minimal time period. Recently, the casting components are produced by WAAM technology in the manufacturing sector, due to their structural complexity and required surface finish. Defects and imperfections occur during different casting techniques. For instance, fabricating Al alloy through traditional method creates problems, which include: (i) shrinkage, (ii) cracks, (iii) gas holes and (iv) inclusions. These defects are rectified by additive layer manufacturing (ALM), or simply AM.

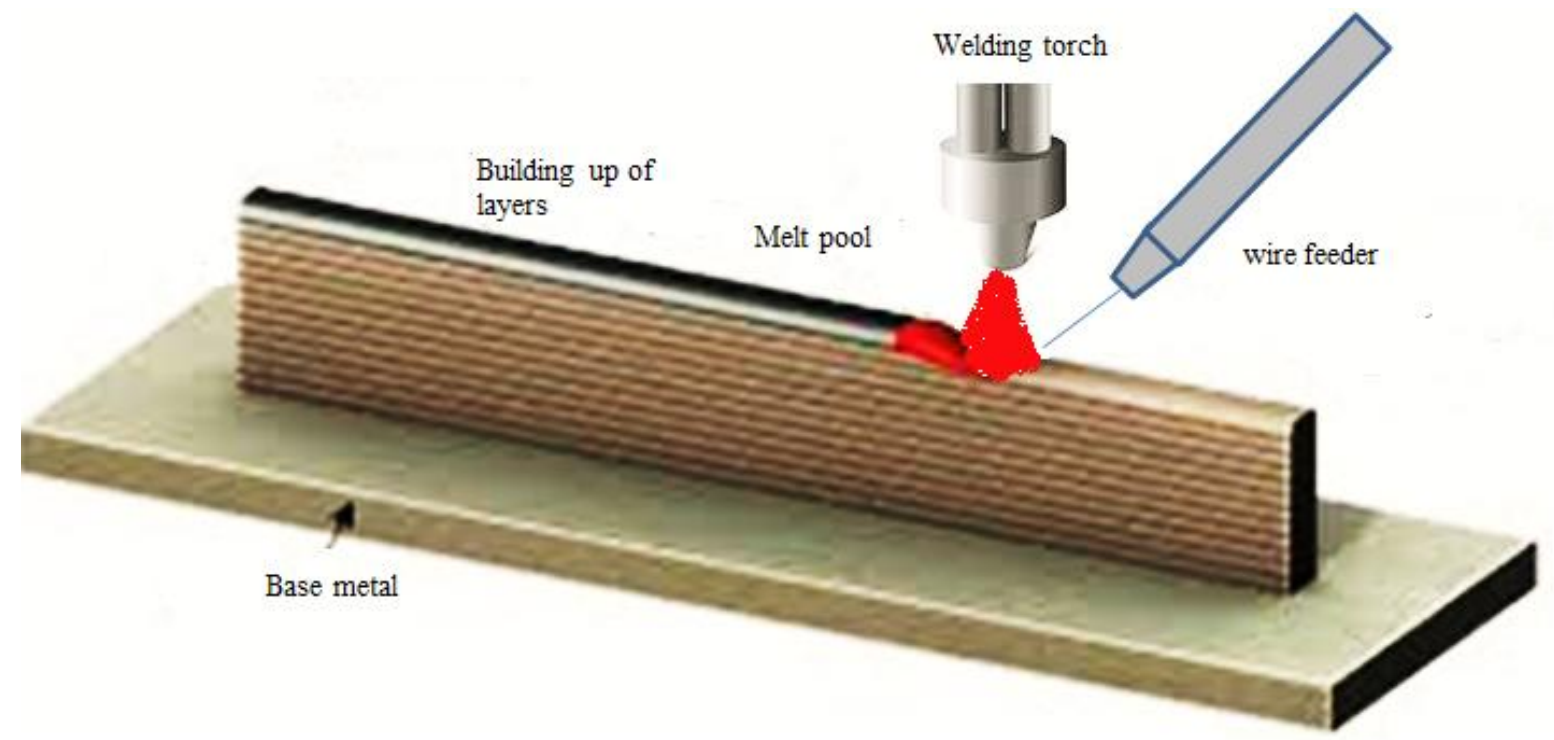

Fig. 5. Wire arc additive manufacturing process. 
The feedstock of WAAM is in the form of wire and electric arc as a heat source, where netshaped complex components with high resolution are made with almost zero wastage. In WAAM technique, two different metals are used altogether, such as: (i) Ni6082 nickel alloy on the surface and (ii) YS308L stainless steel alloy in the inner core. This structure produces high temperatures and corrosion resistance in nature. The $\mathrm{Ni}$ alloy is usually avoided for its weight consideration [87]. Examples of stainless steels fabricated through the WAAM process are 304, 308, 316L and martensitic steel 420 [88-92].

Moreover, the WAAM is a kind of welding process which has a robotic arm or computer numerical control (CNC) gantry that feeds the wire on the substrate with a good mechanical response. The process parameters of WAAM are (i) current, (ii) voltage, (iii) diameter of the wire, (iv) feed rate, (v) welding speed and (vi) printed layer thickness. However, if the welding velocity is high, the WAAM technique produces a crucial imbalance in geometric accuracy, surface roughness and misaligned path [93].

The $316 \mathrm{~L}$ steels cannot be hardened by heat treatment processes. But, it can be hardened by cold working process, resulting to an improved strength [94]. Manufacturing of 316L steel through gas metal arc welding deeply focus on the effect of tensile strength and corrosion properties. As the heat treatment temperature exceeds or higher than $1000^{\circ} \mathrm{C}$, the ultimate tensile strength, yield strength and corrosion resistance increase. The results are further compared with wrought steels, and they are observed to be higher [95]. By varying the process parameters, such as speed pulse and arc velocity, a well efficient and arc stability pattern is obtained. The hardness is enhanced, due to arc speed, which produces fine grains on high cooling rates.

Moving forward, an innovative method of fabrication/WAAM of 316L through cold metal transfer (CMT) and tungsten inert gas (TIG) process produce an anisotropy behavior. The deposition rate of 304 stainless steel on TIG-based WAAM process [96] is comparatively higher than powder-based systems [97]. The WAAM products definitely requires machining after the fabrication, yet the material wastage is less. When the heat input is higher, the yield strength recedes to the base metal, and finishing gets poor [98]. On even supply of heat, the wire melts and bonds with the substrate and these continuous operations build a layer-by-layer deposition. This WAAM process has a limited application than powder bed fusion process, as curve shapes and sharp edges are difficult to form with WAAM process [99]. A new feed wire (metal-cored wire $\mathrm{XC}-45$ contains alloy powder) is used on S355 steel substrate. The structural output shows an anisotropy behavior, better hardness and mechanical strength. The constructed wall possesses pearlite, bainite, ferrite and martensite phase transformation. Microstructural investigation shows 
columnar (elongated) growth is predominant issue with AM process. This can be controlled by modulating laser beam intensity and time based profiles. For example, laser beam on transverse elliptical direction shows equiaxed and mixed epitaxial grain growth [100]. Frequently, this WAAM process has been used in the manufacturing of bars and it allows a more efficient arrangement of reinforcements [101].

There is a limited discussion on the thermal cycle and reheating complex structures, using low carbon steel alloys and duplex stainless steels. The reheating produces a recrystallization effect, which leads to fine-grained structures [102-105]. The post-processing treatment of Cr-Mn stainless steel is observed under microstructural analysis and shows $\delta$-ferrite transformation that leads to the formation of $\mathrm{CrN}$ in the supersaturated state during nitrogen addition. The nitrogen improves the work hardening effect of steel [106]. Notwithstanding, the drawbacks of WAAM process includes heat management, irregularities, porosity and flaws. The deformation occurs, due to residual stresses and component distortion. In order to produce perfect designed components, all the process parameters are monitored with precise knowledge on each individual design. The WAAM technique has a near-future, yet there are many parameter variations, and other such conditions need to be discovered.

\subsection{Powder bed technology}

\subsubsection{Electron beam additive manufacturing}

Electron beam melting (EBM) is the same as that of the laser melting process, which works on an electron beam instead of a laser. The quality of the finished products is comparatively higher than the conventional methods. The EBM is the best suited for industrial applications and has a huge potential for metal AM. The electron beam scans directly on the focus spot and heats the powder granules at an extremely faster rate. The densification is attained on the rapid solidification of layer-by-layer built [107]. Based on the scanning pattern, the melt pool network is designed. On comparing the layer thicknesses of 100 and $200 \mu \mathrm{m}$, the latter has more defects than the former layer thickness. This implies that the layer thickness minimizes the hardness and mechanical properties of the built components. A better quality output is achieved by optimizing the process parameters [108].

Also, heat treatment studies discuss the heating and re-heating effects on the continuous process, which leads to the annealing effect. The microstructural analysis depicts that rapid solidification is achieved on truss structures [109] and the continuous grain boundaries become 
more noticeable on heat treatments. Similarly, the austenite phase is observed on the surface of $316 \mathrm{~L}$, and other phases were less than $0.5 \%$, whereas the microstructure remains the same in all aspects [110]. The EBM produces a defect-free component on $316 \mathrm{~L}$ and 347 stainless steels. The corrosion property of $316 \mathrm{~L}$ is higher than 347 stainless steel $[111,112]$. The formed 316L alloy exhibits a high density, with high strength and ductility. However, the aforementioned properties reduce with a high-temperature fabrication, whereas the toughness is increased. The strength can be improved by varying the process parameters, such as layer thickness, scan speed and build time [113]. Only a limited range of materials are used in EBM. The relevant materials include cobaltchromium, steel, $\mathrm{Ti}$ and $\mathrm{Ni}$ alloys. Moreover, the material used in EBM should be conductive and a vacuum chamber is needed to prevent the interaction of an electron with the environment. The welding features are less in EBM.

EBM process is not only used to manufacture components; they are also used in repairing or re-joining dissimilar metals in their damaged zones. While fabricating the $316 \mathrm{~L}$ alloy on IN718 substrate, cracking occurs due by imposing the IN718 into the 316L steel. However, this is avoided by parameter optimization [114]. The EBM process handles through gas tungsten arc welding, the samples show solid cellular arrangement on top surface and noticeable grain boundaries at the bottom surface. Molybdenum present on the surface enhances the hardness of the samples $[115,116]$. Due to the enrichment of chromium and molybdenum on fusion zone, mechanical properties of the metal are improved, and these results are equivalent to the wrought alloy [117]. The tensile and yield strengths of 316L increase by 76 and $29 \%$, respectively when compared with the wrought alloy. Building 316L cladding on the same substrate, columnar growth occurs along the build direction. This growth is controlled by bilinear dislocation arrays in austenite phase, which improves the densities. Carbide precipitation present on the columnar growth affects the corrosion resistance $[118,119]$. Optimization of the process parameters, such as speed function and focus offset result into an anisotropy behavior with high tensile properties. In order to avoid $\sigma$ phase precipitation at a high-temperature zone, the aforementioned parameters are taken into consideration. In case of EBM, the microstructural analysis is mostly examined when compared with the other studies [120-125]. Practicably, the application of EBM is found in many fields: nuclear, chemical reactors and aviation, to mention but a few [126]. 


\subsubsection{Laser powder bed fusion additive manufacturing}

Selective laser sintering (SLS) provides higher accuracy and surface quality when compared with a fused deposition modeling (FDP) technique. Among AM techniques, the SLS or direct metal laser sintering (DMLS) is a powder-based technique where the binders and base materials are in the form of powder, fused together and formed a functional prototype. SLS is powder based technique that uses a high power laser selectively scans the thin layer of powder, sintered the powder particles in the shape of cross section. The parameters, including particle size, shape, distribution, bulk density and flow must be commensurate with the sintering process [78]. This method is not only applicable to metals, but it also used in the manufacturing of ceramics [127], bio-polymers [128] and composites [129,130]. The SLS process provides a rapid cooling technique, where the properties are enhanced by $\mathrm{T} 6$ heat treatment of $\mathrm{Al}$ alloys [131]. With respect to the building of support structures for the components produced by laser powder bed fusion (Fig. 6), the web support is best, when compared with the tube support, due to ease of removability after finishing the process. The support structure can be removed by hands without using any specific or special tool [132].

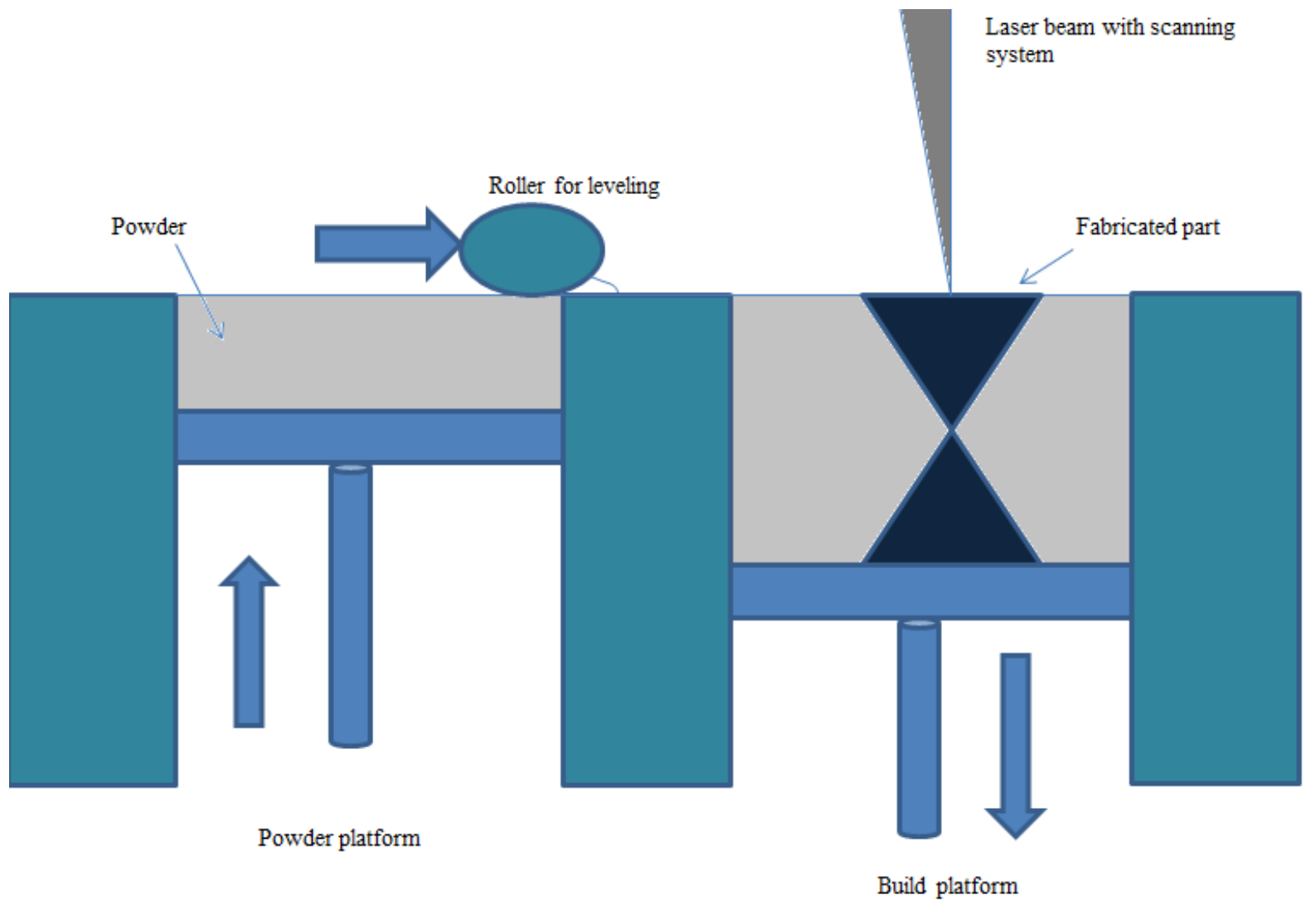

Fig. 6. Laser powder bed fusion process. 
In the 17-4PH AM process, single tracks, single layer hatches and penetration depth are studied. By using high speed camera system, the active illumination technique identifies the defects and irregularities along the building process [133]. Due to the presence of oxides, sulphides and nitrides group of compounds in the grain boundaries at sharp corners lead to fracture or crack on the surface of the metal. In case where the compounds are equiaxed on all ends, it possesses pinning and grain growth development [134]. With AM, the energy input depends upon the porosity of the material. Upon decrease of energy density, porosity increases, and increase of energy input above a certain level balling effect occurs. Therefore, it is important to maintain the energy density in a defined limit [135].

Besides, comparing the laser built additive manufactured and wrought AlSi10Mg, 17-4PH, 316L stainless steels, Ti-6Al-4V, the fatigue strength, ductility and hardness are greatly improved than wrought and annealed material. The high-density metal fabrication prevents the porosity of the component. In DMLS, the built component subjects to hot Isostatic pressure produces a high fatigue life, but other properties show small improvements [136]. The anisotropy behavior of the material significantly affects the properties of steel [137]. Fabrication of a single piece component through laser additive manufacturing (LAM) attracts a high cost budget and hence, it is meant mainly for mass production. The cost rate reduces more than $80 \%$ on increasing multiple pieces of production than single piece production. In the future, the general price development of LAM machinery should be examined, as it has a very big influence in terms of cost [138]. In AM, the density is achieved greatly, whereas the impact strength is slightly lower when compared with wrought alloys [139]. The sintering time and temperature determine the occurrence of porosity. The powder turns to a molten metal during melting and deposits as per the desired dimension and parameters description mentioned.

By defining the process parameters, the porosity levels of the sintered part are maintained [140]. By comparing the residual stress test with destructive evaluation and non-destructive evaluation (neutron diffraction method), it is evident that the deformation is predominantly visible on the prism specimens built in the horizontal direction and more confined on vertically built. The use of 45-degree off-axis scanning creates a reduction in residual stress [141]. For 316L stainless steel fabricated through selective laser melting (SLM) technique with high density gives good results in a corrosive atmosphere. A high performance of constructed parts is observed at an energy density of $333.3 \mathrm{~J} / \mathrm{mm}^{3}$ [142]. 
The post processing treatment, such as shot peening significantly improves the surface morphology. The built DMLS surface shows a needle-like peaks, but the microstructural analysis depicts that the needle dents disappear on shot peening process. Under low scan speed and shot peening, the surface roughness tends to reduce $[143,144]$. LAM manufactured martensitic $410 \mathrm{~L}$ stainless steel exhibits mechanical strength twice that of wrought alloys. In contrast, the austenitic steel shows a lower tensile strength and hardness than martensitic steel [145].

In addition, fabrication of 304L stainless steel with Ti-6Al-4V and vanadium as an interlayer forms a coarse inclusion and poor powder segregation, which supports a decrease in its mechanical strength. Adjacent layer deposition containing $\mathrm{Fe}$ and $\mathrm{Ti}$ results to an embrittlement. Post processing treatments with parameter optimisation promote the recrystallation effects and enhance the mechanical performance [146]. When comparing 304L stainless steel fabricated under two conditions (low and high heat inputs), fine microstructure and good mechanical behavior are obtained for a low linear heat input. The coarser microstructure is visible on the top and bottom of the walls, due to a decrease in cooling rate with an increase in distance from the substrate. This result to a greater reduction in mechanical properties than the annealed one. The martensitic transformation occurs on annealed 304L plate, which shows a high strain rate. This condition can be minimised by additively manufactured steel with high nitrogen pre-alloyed powder that produces austenite phase transformation on annealing, which promotes better properties [147]. With the fabricated SSCX using laser powder bed fusion, the austenitic and martensitic phases are examined by SEM and X-ray diffraction (XRD) analysis. There are no presence of carbide and porosity [148]. A comparative study of 316L stainless steel on three different fabrication techniques, namely; SLM, hot pressing and conventional casting, the microstructure, mechanical and tribological properties are analyzed. The results show a homogenized granular structure without pores, high mechanical strength and a better wear resistance is seen in SLM fabricated alloy [149].

Microstructure and micro hardness were analyzed through an optical microscope and Vicker's hardness tester. It is observed that laser metal deposition samples are defect-free; without cracks or porosity, and with martensitic-dendritic growth structure [150]. The specimen shows dendrite/cellular solidification microstructure in the as-built condition. Whereas, wrought 17-4PH shows BCC/martensitic and FCC in a roughly equal volume fraction. Comparative study of wear and mechanical properties of additively manufactured 17-4PH stainless steel with conventional manufactured wrought specimens is carried out. The results show that the wear rate of additively manufactured $17-4 \mathrm{PH}$ stainless steel is lower than conventional technique, under a dry condition. 
Conversely, additively manufactured 17-4PH stainless steel has a higher wear rate than conventional technique, under a lubrication condition [151]. The mechanical and microstructural characterization of $17-4 \mathrm{PH}$ is studied in different build directions (vertical cylinders and horizontal prisms). The result shows that vertically built samples exhibit lower strength and elongation to failure than horizontally built samples. Also, heat-treated samples show an increase in yield strength, ultimate tensile strength, compressive strength and hardness. Heat-treated samples are less ductile when compared with as-built [152].

Furthermore, an experimental design approach using a fractional factorial orthogonal design based on Taguchi's design matrix has been used to study the micro-hardness and ultimate compressive strength of 17-4PH stainless steel. Four varying process parameters, which include laser power, build orientation, layer thickness and defocus distance are considered. Statistical analysis depicts the effects of optimization chart. The results show that laser power at $270 \mathrm{~W}$, vertical orientation, layer thickness of $30 \mu \mathrm{m}$ and defocus distance of $-6 \mathrm{~mm}$ exhibit an improved mechanical performance $[153,154]$. Study on microstructural analysis of $17-4 \mathrm{PH}$ stainless steel under various heat treatments, atom-probe field ion microscopy (APFIM) and transmission electron microscopy (TEM) show that hardness and yield strength increase after aging at $400{ }^{\circ} \mathrm{C}$, over a prolonged aging $\left(400{ }^{\circ} \mathrm{C}\right.$ at $\left.5000 \mathrm{~h}\right)$ [155]. Using two different atomizing media (nitrogen and water) and two different SLM post-processing (solutionizing at $1050{ }^{\circ} \mathrm{C}$ and $315^{\circ} \mathrm{C}$, aging at $482{ }^{\circ} \mathrm{C}$ for each temperature), mechanical properties and microstructural characterization are analyzed. The results show that gas atomized powder has a single martensitic phase at a low temperature solutionizing of $1050{ }^{\circ} \mathrm{C}$ and aging at $482{ }^{\circ} \mathrm{C}$, whereas water atomized powder has a fully martensitic phase at a high temperature solutionizing and aging. Mechanical properties of the water atomized with high-temperature post-processed alloy are observed to be comparable to gas atomized counterpart. The microstructure of gas-atomized powder after high-temperature treatment has small and large $\mathrm{Cu}$-enriched precipitates, but water atomized shows very fine enriched precipitates that are uniformly distributed in BCC martensitic structure [156]. The effects of defocus distance and the surface roughness as well as the hardness are investigated. It is evident that at a defocus distance of $-4 \mathrm{~mm}$ and laser power of $300 \mathrm{~W}$, it shows better surface properties and higher hardness with neither porosity nor cracks [157].

Also, 17-4PH stainless steel printed through SLM techniques under two different strategies: (1) single scan of each print layer (scan ' $O$ ') and (2) scanning each print layer twice (scan ' $\mathrm{X}$ '). The results show that samples printed with scan ' $X$ ' strategy show higher hardness, relative density and retained austenite [158]. The corrosion test of laser powder bed fusion (LPBF) and wrought $17-4 \mathrm{PH}$ under electrochemical test and immersion exposure in $0.6 \mathrm{M} \mathrm{NaCl}$ depicts that LPBF 
exhibits a better corrosion resistance than wrought [159]. The magnetic, electrical and hardness properties of $17-4 \mathrm{PH}$ steel samples before and after heat treatment with samples built-in vertical direction show that the three properties are not homogeneous when samples are printed vertically. However, there is an homogeneous phase composition with the horizontally fabricated samples $[160,161]$. Mechanical properties of 17-4PH stainless steel are better without post-processing when compared with the traditional method. Hardness vastly decreases during solutionizing and only increases marginally during aging. With solution treated condition, little evidence of martensite is present and the aged condition show no transformation to tempered martensite [162]. Grain refinement through shot peening improves the physical and mechanical properties of 174PH stainless steel. Shot-peening treatment effectively enhances the roughness, hardness, compression yield strength and wear resistance of the specimen [163].

The experimental study of 17-4PH stainless steel on varying scan velocity, hatch spacing and slice thickness with heat-treated and as-built samples are examined. The samples after heat treatment show improved and better properties than as-built counterparts. When changes in composition are combined with the precipitation strengthening, the properties are improved [164]. Corrosion performance of LPBF parts of high density shows slightly higher corrosion performance when compared with wrought samples [165]. Stress relief heat treatment increases the tensile strength, but decreases the yield strength. It also decreases the extent of discontinuity yielding. The within building and build-to-build tensile properties are less repeatable than mature structural alloys, but similar to alloys that are fabricated through AM [166]. Additively manufacture 17-4PH stainless steel and correspondingly fabricated through SLM, both atomized in either argon or nitrogen atmosphere has been comparatively studied. The results show that the correspondingly fabricated through SLM sample show that SLM fabricated martensitic products exhibit hardness Rockwell C (HRC) of 30, while on aged at $482{ }^{\circ} \mathrm{C}$ gives an HRC of 43 . Austenitic products do not exhibit age hardening [167]. The solutionized and aged steels show better yield and ultimate strengths, when compared with additively manufactured steels. Steels that are built under nitrogen atmosphere exhibit a combination of retained austenite and martensite phase and also possess a better fatigue resistance to crack growth. [168]. Considering the comparative study on fatigue strength, wrought alloy shows a slightly higher fatigue strength than additively fabricated steel. The steel samples that are built in vertical direction show a significant lower elongation at breakage than horizontal counterparts [169]. The steel obtained after the post processing processes is defectfree; free from voids [170]. Pitting resistance of a material decreases by the addition of niobium and nitrogen to 17-4PH stainless steel, whereas molybdenum increases the corrosion resistance of the alloy and this is identified by cyclic polarization test. When the corrosion/pitting potential is 
high, then it implies that the corrosion resistance of the material has improved [171]. When impact velocity is higher than $8 \mathrm{~m} / \mathrm{s}$, it means that $17-4 \mathrm{PH}$ stainless steel aged near $460{ }^{\circ} \mathrm{C}$ possesses erosion-corrosion resistance in a single martensite matrix [172].

\section{Concluding remarks}

From this compendious review, the various fabrication processes of stainless steel have been discussed. Though, powder metallurgical processes and casting improve the strength of some materials, but often with porosity. The density of the material in AM is high, when compared to other fabrication techniques. The layer-by-layer fabrication increases the density of the 3D-printed stainless steel components. In a bid to support the green economy, the priority to look forward to achieving manufacturing process that minimizes the consumption of raw materials and enhances the product range is very germane. AM is an outstanding technique by producing stainless steel components that are impossible to manufacture via other techniques.

However, critical and advanced progressive efforts are still required for further development and growth of AM technique. These are necessary to reduce the production/manufacturing cost as well as supporting mass production and printing of large stainless steel components. These challenges are surmountable with the advent of various efficient sophisticated engineering software, robots in manufacturing, artificial intelligence and smart manufacturing.

\section{References}

[1] G. Klančnik, D.S. petrovič, J. Medved, Thermodynamic calculation of phase equilibria in stainless steels, J. Min. Metall. Sect. B Metall. 48 (3) (2012) 383-390.

[2] M. Pohl, O. Storz, T. Glogowski, Effect of intermetallic precipitation on the properties of duplex stainless steel, Mater. Charact. 58 (2007) 65-71.

[3] M. Cortie, M. du Toit, Ferritic stainless steels, Encyclopaedia of materials: Science and Technology (2nd edition), 2001, 3037-3039.

[4] J.M. Torralba, Metal injection molding (MIM) of stainless steel. Handbook of Metal Injection Molding, (2012) 393-414.

[5] C.X. Li, T. Bell, Corrosion properties of plasma nitrided AISI 410 martensitic stainless steel in $3.5 \% \mathrm{NaCl}$ and $1 \% \mathrm{HCl}$ aqueous solutions, Cor. Sci. 48 (2006) 2036-2049.

[6] J. Gausemeier, Thinking ahead the future of additive manufacturing-. Future applications, Heinz Nixdorf Institute, University of Paderborn, 2011. 
[7] M.A. Newell, H.A. Davies, P.F. Messer, D.J. Greensmith, Metal injection moulding scissors using hardenable stainless steel powders, Powder Metall, 48 (2005) 227-230.

[8] G. Pantazopoulos, A. Vazdirvanidis, Metallurgical investigation on fatigue failure of stainless steel chain in a continuous casting machine, Eng. Fail. Anal. 16 (2009) 1623-1630.

[9] H. Kyogotu, S. Komatsu, M. Shinzawa, D. Mizuno, T. Matsuoka, K. Sakaguchi, Influence of microstructural factors on mechanical properties of stainless steel by powder injection moulding, Proc. 2000 Powder Metall. World Cong. 1 (2000) 304-307.

[10] X. Chen, J. Li, X. Cheng, B. He, H. Wang, Z. Huang Z, Microstructure and mechanical properties of the austenitic stainless steel 316L fabricated by gas metal arc additive manufacturing, Mater. Sci. Eng. A 703 (2017) 567-577.

[11] L. Wang, J. Xue, Q. Wang, Correlation between arc mode, microstructure and mechanical properties during wire arc additive manufacturing of $316 \mathrm{~L}$ stainless steel, Mater. Sci. Eng. A 751 (2019) 183-190.

[12] Y.V. Myachina, E.A. Darenskayaa, O.Y. Vaulinaa, S.P. Buyakovaa, I.V. Turuntaevb, S.N. Kulkova, Structure and properties of steel produced by metal injection molding, Inorgan. Mater. Appl. Res. 8 (2) (2017) 331-334.

[13] H.O. Gulsoy, S. Salman, Microstructures and mechanical properties of injection molded 174PH stainless steel powder with nickel boride additions, J. Mater. Sci. 40 (2005) 3415-3421.

[14] R. Machaka, Metal injection moulding of a 17-4PH stainless steel: a comparative study of mechanical properties, IOP Conf. Series Mater. Sci. Eng. 430 (2018) 012033.

[15] J.C. Gelin, T. Barriere, M. Dutilly, Experiments and computational modeling of metal injection molding for forming small parts, ClRP Annals 48 (1) (1999) 179-182.

[16] I. Costa, S.O. Rogerob, M. Saikic, R.A. Marquesd, J.R. Rogeroe, Corrosion resistance and cytotoxicity study of 17-4PH steels produced by conventional metallurgy and powder injection molding, Mater. Sci. Forum 591-593 (2008) 18-23.

[17] K. Okubo, S. Tanaka, H. Ito, The effects of metal particle size and distributions on dimensional accuracy for micro parts in micro metal injection molding, Microsyst. Technol. 16 (2010) 2037-2041.

[18] P. Imgrunda, A. Rota, A. Simchi, Microinjection moulding of 316L/17-4PH and 316L/Fe powders for the fabrication of magnetic-non-magnetic bimetals, J. Mater. Proc. Technol. 200 (2008) 259-264.

[19] B.A. Mathew, Mathson Industries Inc., 2002, www.metal-powder.net. 
[20] K. Yu, S. Ye, W. Mo, Y. Lv, H. Jiang, R. Ma, C.T. Kwok, P. Yu, Oxygen content control in metal injection molding of $316 \mathrm{~L}$ austenitic stainless steel using water atomized powder, $\mathrm{J}$. Manuf. Proc. 50 (2020) 498-509.

[21] V. Piotter, T. Gietzelt, L. Merz, Micro powder-injection moulding of metals and ceramics, Sadhana 28 (1, 2) (2003) 299-306, https://doi.org/10.1007/BF02717139.

[22] V. Piotter, W. Bauer, R. Knitter, M. Mueller, T. Mueller, K. Plewa, Powder injection moulding of metallic and ceramic micro parts, Microsyst. Technol. 17 (2011) 251-263.

[23] D. Heaney, R. Zauner, C. Binet, K. Cowan, J. Piemme, Variability of powder characteristics and their effect on dimensional variability of powder injection molded components, J. Powder Metall. 47 (2) (2004) 145-150.

[24] P.V. Muterlle, M. Perina, A. Molinari, Mechanical properties and corrosion resistance of vacuum sintered MIM 316L stainless steel containing delta ferrite, Powder Injec. Mould. Inter. 4 (2) (2010) 66-70.

[25] L. Ammosova, K. Mönkkönen, M. Suvanto, Precise fabrication of microtextured stainless steel surfaces using metal injection moulding, Prec. Eng. 62 (2020) 89-94, https://doi.org/10.1016/j.precisioneng.2019.11.012

[26] P-H. Huang, M-J. Guo, A study on the investment casting of 17-4PH stainless steel helical impeller of centrifugal pump, Mater. Res. Innov. 19 (9) (2015) 79-81, https://doi.org/10.1179/1432891715Z.0000000001924.

[27] Y. Chun-lei, Z. Qi, Simulation on filling and solidification process of stainless steel impeller's in investment casting, Found. Technol. 33 (5) (2012) 593-595.

[28] J. Frömert, T.G. Lott, A.M. Matz, N. Jost, Investment casting and mechanical properties of open-cell steel foams. Adv. Eng. Mater. 21 (6) (2019) 1900396, https://doi.org/10.1002/adem.201900396.

[29] Reliance Foundary, www.reliance foundry.com/investmment casting.

[30] W.F. Wang, X. Guo, F. Wang, Improvement of the investment casting process used to the production of stainless steel impeller, Found. Equip. Technol. 3 (2012) 21-22.

[31] S. Kalpajian, S.R. Schmid, Manufacturing Engineering and Technology, 6th Edition, Pearson publications, 2010.

[32] F. Zarei, H. Nuranian, K. Shirvani, In-situ formation of Al-alloyed surface layer on HH309 stainless steel by casting process, Mater. Res. Express 6 (2019) 096573, https://doi.org/10.1088/2053-1591/ab302a.

[33] T. Wegrzyn, Delta ferrite in stainless steel weld metals, Weld. Inter. 6 (9) (1992) 690-694, https://doi.org/10.1080/09507119209548267. 
[34] Y. Zhong, L-E. Rannar, L. Liu, A. Koptyug, S. Wikman, J. Olsen, D. Cui, Z. Shen, Additive manufacturing of $316 \mathrm{~L}$ stainless steel by electron beam melting for nuclear fusion applications, J. Nucl. Mater. 486 (2017) 234-245.

[35] S.H. Kim, H.K. Moon, T. Kang, C.S. Lee, Dissolution kinetics of delta ferrite in AISI 304 stainless steel produced by strip casting process, Mater. Sci. Eng. A 356 (2003) 390-398.

[36] J.K. Kuo, P.H. Huang, M.J. Guo , Removal of Cr-Mo alloy steel components from investment casting gating system using vibration-excited fatigue failure. Int. J. Adv. Manuf. Technol. 89 (2017) 101-111.

[37] Y.Y. Li, D.C. Tsai, W.S. Hwang, Numerical simulation of the solidification microstructure of a 17-4PH stainless steel investment casting and its experimental verification, Model. Simul. Mater. Sci. Eng. 16 (2008) 045009.

[38] M. Raza, R. Svenningsson, M. Irwin, Experimental study of the filling of thin-walled investment castings in 17-4PH stainless steel, Metall. Found. Eng. 41 (2) (2015) 85-98.

[39] D.F. Susan, T.B. Crenshaw, J.S. Gearhart, The effects of casting porosity on the tensile behavior of investment cast 17-4PH stainless steel, J. Mater. Eng. Perferm. 24 (2015) 29172924.

[40] P-H. Huang, W-J. Huang, Preventing shrinkage defects in investment casting of SUS310 stainless steel feather keys, IOP Conf. Series: Earth Envir. Sci. 186 (2018) 012001.

[41] J-D. Kwon, J-C. Park, Y-S. Lee, W-H. Lee, Y-W. Park, An investigation of the degradation characteristics for casting stainless steel, CF8M, under high temperatures, Nucl. Eng. Des. 198 (2000) 227-240.

[42] M. Blomacher, E. Lange, M. Schwarz, D. Weinand, H. Wohlfromm, Powder injection molding of martensitic stainless steels, in Advances in Powder Metallurgy and Particulate Materials, Metal Powder Industries Federation, Princeton, NJ, USA, (1998) 5131-5141.

[43] P-H. Huang, L.K-L. Shih, H-M. Lin, C-I. Chu, C-S. Chou, Novel approach to investment casting of heat-resistant steel turbine blades for aircraft engines, Inter. J. Adv/ Manuf. Technol. 104 (2019) 2911-2923, https://doi.org/10.1007/s00170-019-04178-z.

[44] S. Jayet-Gendrot, P. Gilles, C. Migne, Behavior of duplex stainless steel casting defects under mechanical loadings, Nucl. Eng. Des. 197 (2000) 141-153.

[45] J. Kazior, A. Szewczyk-Nykiel, T. Pieczonka, M. Hebda, M. Nykiel, Properties of precipitation hardening 17-4PH stainless steel manufactured by powder metallurgy technology, Adv. Mater. Res. 811 (2013) 87-92.

[46] Y.H. Yao, J.F. Wei, Z.P. Wang, Effect of long-term thermal aging on the mechanical properties of casting duplex stainless steels, Mater. Sci. Eng. A 551 (2012) 116- 121. 
[47] P. Hausild, C. Berdin, P. Bompard, N. Verdiere, Ductile fracture of duplex stainless steel with casting defects, Inter. J. Pres. Vess. Piping 78 (2001) 607-616.

[48] M. Mahmoudi, A. Elwany, A. Yadollahi, S.M. Thompson, L. Bian, N. Shamsaei, Mechanical and microstructural characterization of selective laser melted 17-4PH stainless steel, Rap. Prototyp. J. 23 (2) (2017) 280-294, http://dx.doi.org/10.1108/RPJ-12-2015-0192.

[49] L. Hu, H. Peng, I. Baker, L. Li, W. Zhang, T. Ngai, Characterization of high-strength high-nitrogen austenitic stainless steel synthesized from nitrided powders by spark plasma sintering, Mater. Character. 152 (2019) 76-84.

[50] T. Meesak, C. Thedsuwan, Corrosion behaviours of stainless steel parts formed by powder metallurgy process, Mater. Today Proc. 5 (2018) 9560-9568.

[51] N.T. Aboul Khair, I. Maskery, C. Tuck, I. Ashcraft, N. M.Everitt, The microstructure and mechanical properties of selectively laser melted AlSi10Mg: The effect of a conventional T6-like heat treatment, Mater. Sci. Eng. A, 667 (2016) 139-146.

[52] D. Ferreño, J.A. Álvarez, E. Ruiz, D. Méndez, L. Rodríguez, D. Hernández, Failure analysis of a Pelton turbine manufactured in soft martensitic stainless steel casting, Eng. Fail. Analy. 18 (2011) 256-270.

[53] E.A. Ariza, A.P. Tschiptschin, C.R.F. Azevedo, Failure analysis of a martensitic stainless steel (CA-15M) roll manufactured by centrifugal casting. Part II: Thermal stress analysis by FEA, Eng. Fail. Analy. 48 (2015) 78-93.

[54] H.T. Liu, Z.Y. Liu, Y.Q. Qiu, G.M. Cao, C.G. Li, G.D. Wang, Characterization of the solidification structure and texture development of ferritic stainless steel produced by twinroll strip casting, Mater. Character. 60 (2009) 79-82.

[55] G. Pantazopoulos, A. Vazdirvanidis, Metallurgical investigation on fatigue failure of stainless steel chain in a continuous casting machine, Eng. Fail. Analy. 16 (2009) 1623-1630.

[56] M. Simsir, L.C. Kumruog `u, A. Özer, An investigation into stainless-steel/structural-alloysteel bimetal produced by shell mould casting, Mater. Des. 30 (2009) 264-270.

[57] P.K. Samal, N. Nandivada, I. Hauer, A.B. Hoganas, Properties Of 17-4 PH Stainless Steel Produced via Press and Sinter Route, PM2008 World Congress in Washington, USA (2008) $1-12$.

[58] F. Akhtara, L. Ali, F. Peizhong, J.A. Shah, Enhanced sintering, microstructure evolution and mechanical properties of 316L stainless steel with $\mathrm{MoSi}_{2}$ addition, J. Alloys Comp. 509 (2011) 8794-8797.

[59] C. Keller, K. Tabalaiev, G. Marnier, J. Noudem, X. Sauvage, E. Hug, Influence of spark plasma sintering conditions on the sintering and functional properties of an ultra-fine 
grained316Lstainlesssteel obtained from ball-milled powder, Mater. Sci. Eng. A 665 (2016) $125-134$.

[60] M. Peruzzo, T.D. Beux, M.F.C. Ordo nez, R.M. Souza, M.C.M. Farias, High-temperature oxidation of sintered austenitic stainless steel containing boron or yttria, Corros. Sci. 129 (2017) 26-37, http://dx.doi.org/doi:10.1016/j.corsci.2017.09.002.

[61] C. Balázsia, H.R.B. Zine, M. Furko, Z. Czigány, L. Almásy, V. Ryukhtin, et al., Microstructural and magnetic characteristics of ceramic dispersion strengthened sintered stainless steels after thermal ageing, Fus. Eng. Des. 145 (2019) 46-53.

[62] M. Peruzzo, F.L. Serafini, M.F.C. Ordoñez, R.M. Souza, M.C.M. Farias, Reciprocating sliding wear of the sintered 316L stainless steel with boron additions, Wear 422-423 (2019) $108-118$.

[63] M.F.C. Ordoñez, C.L.G. Amorim, I. Krindges, C. Aguzzoli, I.J.R. Baumvol, C.A. Figueroa, A. Sinatora, R.M. Souza, M.C.M. Farias, Microstructure and micro-abrasive wear of sintered yttria-containing 316L stainless steel treated by plasma nitriding, Surf. Coat. Technol. 374 (2019) 700-712.

[64] A. Dudek, R. Włodarczyk, Effect of sintering atmosphere on properties of porous stainless steel for biomedical applications, Mater. Sci. Eng. C 33 (2013) 434-439.

[65] S. Pandya, K.S. Ramakrishna, A.R. Annamalai, A. Upadhyaya, Effect of sintering temperature on the mechanical and electrochemical properties of austenitic stainless steel, Mater. Sci. Eng. A 556 (2012) 271-277.

[66] Y. Xia, B. Ying-Long, X. Meng, G. Shi-Ju, Effect of additive Cu-10Sn on sintering behavior and wear resistance of 316L stainless steel, J. Iron Steel Res. Inter. 20 (7) (2013) 84-88.

[67] S.O. Akinwamide, O.J. Akinribide, M. Mafafo, M. Phumlani, B.A. Obadele, B.T. Abe, et al., Effect of TiN addition on corrosion behavior of spark plasma sintered 304L austenitic stainless steel in chloride media, Mater. Today Proc. 28 (2) (2020) 384-772, https://doi.org/10.1016/j.matpr.2019.10.018.

[68] T. Makhmutov, N. Razumov, A. Kim, S. Ganin, A. Shamshurin, A. Popovich, et al., Microstructure and mechanical properties of high-nitrogen $16 \mathrm{Cr}-2 \mathrm{Ni}-\mathrm{Mn}-\mathrm{Mo}-\mathrm{xN}$ stainless steel obtained by powder metallurgy techniques, Mater. Today Proc. 30 (3) (2020) 768-387, https://doi.org/10.1016/j.matpr.2020.01.564.

[69] A.N. Acar, A.K. Eksi, A. Ekicibil, Effect of pressure on the magnetic and structural properties of X2CrNiMo17-12-2 austenitic stainless steel prepared by powder metallurgy method, J. Mole. Struct. 1198 (2019) 126876. 
[70] N. Tosangthum, O. Coovattanachai, R. Krataitong, M. Morakotjinda, A. Daraphan, B. Vetayanugul, et al., Density and strength improvement of sintered 316L stainless steel, Chiang Mai J. Sci. 33 (1) (2006) 53-66.

[71] H.O“. Gu“lsoy, T. Baykara, S. O“zbek, Injection moulding of 316L stainless steels reinforced with nanosize alumina particles, Powder Metall. 54 (3) (2013) 360-365.

[72] B. Flipon, C. Keller, L. Garcia de la Cruz, E. Hug, F. Barbe, Tensile properties of spark plasma sintered AISI 316L stainless steel with unimodal and bimodal grain size distributions, Mater. Sci. Eng. A 729 (2018) 249-256.

[73] E. Protopappas, C.A. Smal, F.G. De Lange, Mechanical properties of a 316L forging material modified for resistance to sensitization, INFACON 6. Proc. $1^{\text {st }}$ Inter. Chrom. Steel Alloys Cong. Cape Town, SAIMM, Johannesburg, South Africa 2 (199) 97-103.

[74] L. Bian, S.M. Thompson, N. Shamsaei. Mechanical properties and microstructural features of direct laser-deposited Ti-6Al-4V. J. Mater. 67( 3) (2015) 629-638.

[75] D.L. Wimpenny, P.M. Pandey, L.J. kumar, C.G.K. Nair, Advances in 3D printing and Additive Manufacturing Techniques, ISBN 978-981-10-0811-5, Springer publications (2017).

[76] P. Suri, R.P. Kososki, R.M. German, Microstructural evolution of injection molded gas and water atomised 316L stainless steel powder during sintering, Mater. Sci. Eng. A 402 (2005) 341-348.

[77] A. Gaard, P. Krakhmalev, J. Bergstom, Microstructural characterization and wear behaviour of (Fe,Ni)-TiC MMC prepared by DMLS, J. Alloys Comp. 421 (2006) 166-171.

[78] R.S. Evans D.L. Bourell J.J. Beaman M.I. Campbell, Rapid manufacturing of silicon carbide composites, Rap. Prototyp. J. 11 (1) 37-40.

[79] A. Levy, A. Miriyev, A. Elliott, S.S. Babu, N. Frage, Additive manufacturing of complexshaped graded TiC/steel composites, Mater. Des. 118 (2017) 198-203, https://doi.org/10.1016/j.matdes.2017.01.024.

[80] J. Li, T. Monaghan, T.T. Nguyen, R.W. Kay, R.J. Friel, R.A. Harris, Multifunctional metal matrix composites with embedded printed electrical materials fabricated by ultrasonic additive manufacturing, Comp. Part B Eng. $113 \quad$ (2017) 324-354, https://doi.org/10.1016/j.compositesb.2017.01.013.

[81] D. Herzog, V. Seyda. E. Wycisk, C. Emmelmann, Additive manufacturing of metals, Acta Mater. 117 (2016) 371-392. 
[82] Y. Zhang, W. Gao, D. Ramanujan, K. Ramani, Y. Chen, C.B. Williams, et al., The status, challenges and future of additive manufacturing in engineering, Comp. Des. 69 (2015) 6589.

[83] P.M.S. Almeida, S. Williams, Innovative process model of Ti-6Al-4V additive layer manufacturing using cold metal transfer (CMT), Conf. Proc. $21^{\text {st }}$ Annual Inter. Solid Freeform Fabric. Sympos. (2014), https://www.researchgate.net/publication/51999200.

[84] Y. Liu, C. Liu, W. Liu, Y. Ma, S. Tang, C. Liang, et al., Optimization of parameters in laser powder deposition AlSi10Mg alloy using Taguchi method, Optics Laser Technol. 111 (2019) 470-480, https://doi.org/10.1016/j.optlastec.2018.10.030.

[85] Y. Li, Y. Hu, W. Cong, L. Zhi, Z. Guo, Additive manufacturing of alumina using laser engineered net shaping: Effects of deposition variables, Ceram. Int. 43 (2017) 7768-7775, https://doi.org/10.1016/j.ceramint.2017.03.085.

[86] B.P. Conner, G.P. Manogharan, A.N. Martof, L.M. Rodomsky, C.M. Rodomsky, D.C. Jordan, et al., Making sense of 3-D printing: Creating a map of additive manufacturing products and services, Addit. Manuf. 1 (2014) 64-76.

[87] T. Abe, H. Sasahara, Dissimilar metal deposition with a stainless steel and nickel-based alloy using wire and arc-based additive manufacturing, Prec. Eng. 45 (2016) 387-395, http://dx.doi.org/10.1016/j.precisioneng.2016.03.016.

[88] C.V. Haden, G. Zeng, F.M. Cater III, C. Ruhl, B.A. Krick, D.G. Harlow, Wire and arc additive manufactured steel : Tensile and wear properties, Addit. Manuf. 16 (2017) 115-123, https://doi.org/10.1016/j.addma.2017.05.010.

[89] O. Yilmaz, A.A. Ugla, Microstructure characterization of SS308LSi components manufactured by GTAW-based additive manufacturing: Shaped metal deposition using pulsed current arc, Int. J. Adv. Manuf. Technol. 89 (2017) 13-25, https://doi.org/10.1007/s00170-016-9053-y.

[90] A. Queguineur, G. Rückert, F. Cortial, J.Y. Hascoët, Evaluation of wire arc additive manufacturing for large-sized components in naval applications. Weld. World. 62 (2018) 259-266, https://doi.org/10.1007/s40194-017-0536-8.

[91] L. Wang, J. Xue, Q. Wang, Correlation between arc mode, microstructure, and mechanical properties during wire arc additive manufacturing of $316 \mathrm{~L}$ stainless steel. Mater. Sci. Eng. A 751 (2019) 183-190, https://doi.org/10.1016/j.msea.2019.02.078.

[92] J. Ge, J. Lin, Y. Chen, Y. Lei, H. Fu, Characterization of wire arc additive manufacturing 2Cr13 part: Process stability, microstructural evolution, and tensile properties. J. Alloy. Comp. 748 (2018) 911-921, https://doi.org/10.1016/j.jallcom.2018.03.222. 
[93] V. Laghi, M. Palerm, G. Gasparini, V.A. Girelli, T. Trombetti, Geometrical characterization of wire-and-arc additive manufactured steel elements, Adv. Mater. Lett. 10 (10) (2019) 695699.

[94] AZO Materials, Stainless steel-grade 316L-Properties, fabrication and applications (UNS S31603) (2004), https://www.azom.com/article.aspx?ArticleID=2382.

[95] X. Chen, J. Li, X. Cheng, H. Wang, Z. Huang, Effect of heat treatment on microstructure, mechanical and corrosion properties of austenitic stainless steel 316L using arc additive manufacturing, Mater. Sci. Eng. A 715 (2018) 307-314.

[96] M. Dinovitzer, X. Chen, J. Laliberte, X. Huang, H. Frei, Effect of wire and arc additive manufacturing (WAAM) process parameters on bead geometry and microstructure, Addit. Manuf. 26 (2019) 138-146, https://doi.org/10.1016/j.addma.2018.12.013.

[97] D. Ding, Z. Pan, D. Cuiuri, and H. Li, Wire-feed additive manufacturing of metal components: technologies, developments and future interests, Int. J. Adv. Manuf. Technol. $81(1-4)(2015)$ 465-481.

[98] M. Eriksson, M. Lervåg, C. Sørensen, A. Robertstad, B.M. Brønstad, B. Nyhus, et al., Additive manufacture of superduplex stainless steel using WAAM, MATEC Web of Conf. 188 (2018) 03014.

[99] A. Gualco, H.G. Svoboda, E.S. Surian, L.A. De Vedia, Effect of welding procedure on wear behaviour of a modified martensitic tool steel hardfacing deposit. Mater. Des. 31 (9) (2010) 4165-4173.

[100] J. Mehnen, J. Ding, H. Lockett, P. Kazanas, Design study for wire and arc additive manufacture. Int. J. Prod. Dev. 19 (2014) 2-20.

[101] J-K. Kuo, P-K. Huang, H-Y. Lai, J-R. Chen, Optimal gating system design for investment casting of $17-4 \mathrm{PH}$ stainless steel enclosed impeller by numerical simulation and experimental verification. Inter. J. Adv. Manuf. Technol. 92 (2017) 1093-1103, https://doi.org/10.1007/s00170-017-0198-0.

[102] N. Rodriguez, L. Vazquez, I. Huarte, E. Arruti, I. Tabernero, P. Alvarez, Wire and arc additive manufacturing: a comparison between CMT and top TIG process applied to stainless steel, Weld. World 62 (5) (2018) 1083-1096.

[103] A. Queguineur, G. Ruckert, F. Cortial, J.Y. Hascoet, Evaluation of wire arc additive manufacturing for large-sized components in naval applications, Weld. World 62 (2) (2018) 259-266. 
[104] T.A. Rodrigues, V. Duarte, J.A. Avila, T.G. Santos, R.M. Miranda, J.P. Oliveira, Wire and arc additive manufacturing of HSLA steel: Effect of thermal cycles on microstructure and mechanical properties. Addit. Manuf. 27 (2019) 440-450.

[105] V.A. Hosseini, M. Högström, K. Hurtig, M.A.V. Bermejo, L-E. Stridh, L. Karlsson, Wirearc additive manufacturing of a duplex stainless steel: Thermal cycle analysis and microstructure characterization. Weld. World 63 (2019) 975-987.

[106] X. Zhang, Q. Zhou, K. Wang, Y. Peng, J. Ding, J. Kong, S. Williams, Study on microstructure and tensile properties of high nitrogen $\mathrm{Cr}-\mathrm{Mn}$ steel processed by CMT wire and arc additive manufacturing. Mater. Des. 166 (2019) 107611, https://doi.org/10.1016/j.matdes.2019.107611.

[107] A. Koptioug, L.E. Rännar, M. Bäckström, S.Z. Jian, New metallurgy of additive manufacturing in metal: experiences from the material and process development with electron beam melting technology (EBM), Mater. Sci. Forum 879 (2016) 996-1001.

[108] V.V. Popov Jr, A. Katz-Demyanetz, A. Kovalevsky, R. Biletskiy, E. Strokin, A. Garkun, M. Bamberge, Effect of the hatching strategies on mechanical properties and microstructure of SEBM manufactured Ti-6Al-4V specimens, Lett. Mater. 8 (2018) 468-472. https://doi.org/10.22226/2410-3535-2018-4-468-472.

[109] C.J. Smith, F. Derguti, E.H. Nava, M. Thomas, S. Tammas-Williams, S. Gulizia, et al., Dimensional accuracy of electron beam melting (EBM) additive manufacture with regard to weight optimized truss structures, J. Mater. Process. Technol. 229 (2016) 128-138.

[110] J. Olsén, Z. Shen, L. Liu, A. Koptyug, L-E. Rännar, Micro- and macro-structural heterogeneities in 316L stainless steel prepared by electron-beam melting, Mater. Character. 141 (2018) 1-7, https://doi.org/10.1016/j.matchar.2018.04.026.

[111] S. Basak, K.K. Sahu, S.K. Sharma, J.D. Majumdar, Studies on electron beam surface melting of AISI 316 stainless steel and AISI 347 stainless steel, Proc. Manuf. 7 (2016) 647-653.

[112] L-E. Rännar, A. Koptyug, J. Olsén, K. Saeidi, Z. Shen, Hierarchical structures of stainless steel 316L manufactured by electron beam melting, Addit. Manuf. 17 (2017) 106-112.

[113] A. Hinojos, J. Mireles, A. Reichardt, P. Frigola, P. Hosemann, L.E. Murr, et al., Joining of Inconel 718 and 316 stainless steel using electron beam melting additive manufacturing technology, Mater. Des. 94 (2016) 17-27.

[114] V.V. Popov, A. Katz-Demyanetz, A. Garkun, M. Bamberger, The effect of powder recycling on the mechanical properties and microstructure of electron beam melted Ti-6Al-4V specimens, Addit. Manuf. 22 (2018) 834-843, https:// doi.org/10.1016/j.addma.2018.06.003. 
[115] T. Pasang, A. Kirchner, U. Jehring, M. Aziziderouei, Y. Tao, C-P. Jiang, et al., Microstructure and mechanical properties of welded additively manufactured stainless steels SS316L, Met. Mater. Inter. 25 (2019) 1278-1286, https://doi.org/10.1007/s12540-01900264-9.

[116] I.A. Segura, J. Mireles, D. Bermudez, C.A. Terrazas, L.E. Murr, K. Li, et al., Wicker, Characterization and mechanical properties of cladded stainless steel 316L with nuclear applications fabricated using electron beam melting, J. Nucl. Mater. 507 (2018) 164-176, https://doi.org/10.1016/j.jnucmat.2018.04.026.

[117] M. Doyle, K. Agarwal, W. Sealy, K. Schull, Effect of layer thickness and orientation on mechanical behavior of binder jet stainless steel 420 + bronze parts, Proc. Manuf. 1 (2015) 251-262, https://doi.org/10.1016/j.promfg.2015.09.016.

[118] C. Wang, X. Tan, E. Liu, S. Beng Tor, Process parameter optimization and mechanical properties for additively manufactured stainless steel 316L parts by selective electron beam melting, Mater. Dis. 147 (2018) 157-166, https://doi.org/10.1016/j.matdes.2018.03.035.

[119] L-E. R“annar, A. Koptyug, J. Ols'en, K. Saeidi, Z. Shen, Hierarchical structures of stainless steel 316L manufactured by electron beam melting, Addit. Manuf. 195 (2017) 106-112, http://dx.doi.org/10.1016/j.addma.2017.07.003.

[120] A. Hinojos, J. Mireles, A. Reichardt, P. Frigola, P. Hosemann, L.E. Murr, et al., Joining of Inconel 718 and 316 stainless steel using electron beam melting additive manufacturing technology, Mater. Des. 94 (2016) 17-27, https://doi.org/10.1016/j.matdes.2016.01.041.

[121] B. Joseph, D. Katherasan, P. Sathiya, C.V.S. Murthy, Weld metal characterization of 316L(N) austenitic stainless steel by electron beam welding process, Int. J. Eng. Sci. Tech. 4 (2) (2012) 169-176.

[122] M. GokulAnanth, B.S. Babu, P. Chakravarthy, K. Jayakumar, A. Manickavasagam, N.V.S Arunprakash, et al., Experimental investigations on electron beam welding of austenetic/ferritic stainless steel for space applications, Int. J. Res. Mech. Eng. Tech. 3 (2) (2013) 45-50.

[123] G.D. Raasch, Z.A. Munir, The effect of electron beam welding on various properties of three austenitic stainless steels, J. Mat. Sci. 13 (5) (1978) 1061-1074.

[124] H. Hemmer, Q. Grong, A process model for the heat-affected zone microstructure evolution in duplex stainless steel weldments: Part I. the model, Metall. Mat. Trans. 30 (11) (1999) 2915-2929.

[125] S. Afkhami, M. Dabiri, S.H. Alavi, T. Björk, A. Salminen, Fatigue characteristics of steels manufactured by selective laser melting, Int. J. Fatigue 122 (2019) 72-83 
[126] S. Song, Z. Gao, B. Lu, C. Bao, B. Zheng, L. Wang, Performance optimization of complicated structural $\mathrm{SiC} / \mathrm{Si}$ composite ceramics prepared by selective laser sintering, Ceram. Int. 46 (2020) 568-575.

[127] S. Singamneni, R. Velu, M.P. Behera, S. Scott, P. Brorens, D. Harland, et al., Selective laser sintering responses of keratin-based bio-polymer composites, Mater. Des. 183 (2019) 108087.

[128] R. Hong, Z. Zhao, J. Leng, J. Wu, J. Zhang, Two-step approach based on selective laser sintering for high performance carbon black/ polyamide 12 composite with 3D segregated conductive network, Compos. B Eng. $176 \quad$ (2019) 107214, https://doi.org/10.1016/j.compositesb.2019.107214.

[129] A. Katz-Demyanetz, V.V. Popov, A. Kovalevsky, D. Safranchik, A. Koptyug, Powder-bed additive manufacturing for aerospace application: Techniques, metallic and metal/ ceramic composite materials and trends, Manuf. Rev. 6 (5) (2019) 1-13, https://doi.org/10.1051/mfreview/2019003.

[130] J-P. Järvinena, V. Matilainena, X. Lia, H. Piilia, A. Salminena, I. Mäkeläc, et al., Characterization of effect of support structures in laser additive manufacturing of stainless steel, Phys. Proc. 56 ( 2014 ) 72 - 81, https://doi.org/10.1016/j.phpro.2014.08.099.

[131] V-P. Matilainen, H. Piili, A. Salminen, O. Nyrhilä, Preliminary investigation of keyhole phenomena during single layer fabrication in laser additive manufacturing of stainless steel, Phys. Proc. 78 ( 2015) 377 - 387, https://doi.org/10.1016/j.phpro.2015.11.052.

[132] Y. Sun, R.J. Hebert, M. Aindow, Non-metallic inclusions in 17-4PH stainless steel parts produced by selective laser melting, Mater. Des. 140 (2018) 153-162, https://doi.org/10.1016/j.matdes.2017.11.063.

[133] M. Islam, T. Purtonen, H. Piili, A. Salminen, O. Nyrhilä, Temperature profile and imaging analysis of laser additive manufacturing of stainless steel, Phys. Proc. 41 ( 2013 ) 835-842, https://doi.org/10.1016/j.phpro.2013.03.156.

[134] Todd M. Mower n, Michael J. Long, Mechanical behavior of additive manufactured, powder-bed laser-fused materials, Mater. Sci. Eng. A 651 (2016) 198-213, https://doi.org/10.1016/j.msea.2015.10.068.

[135] T. Niendorf, S. Leuders, A. Riemer, H.A. Richard, T. TroSter, D. Schwarze, Highly anisotropic steel processed by selective laser melting, Metall. Mater. Trans. B 44 (2013) 794796, https://doi.org/10.1007/s11663-013-9875-z. 
[136] H. Piili, A. Happonenb, T. Väistö, V. Venkataramanan, J. Partanen, A. Salminen, Cost estimation of laser additive manufacturing of stainless steel, Phys. Proc. 78 ( 2015) 388-396, https://doi.org/10.1016/j.phpro.2015.11.053.

[137] I. Tolosa, F. Garciandía, F. Zubiri, F. Zapirain, A. Esnaola, Study of mechanical properties of AISI 316 stainless steel processed by "selective laser melting", following different manufacturing strategies, Int. J. Adv. Manuf. Technol. 51 (2010) 639-647.

[138] B. Verlee, T. Dormal, J. Lecomte-Beckers, Density and porosity control of sintered 316L stainless steel parts produced by additive manufacturing, Powder Metall. 55 (4) (2012) 260265.

[139] A.S. Wu, D.W. Brown, M. Kumar, G.F. Gallegos, W.E. King, An experimental investigation into additive manufacturing-induced residual stresses in 316L stainless steel, Metall. Mater. Trans. A 45 (2014) 6260-6270.

[140] C. Barile, C. Casavola, S.L. Campanelli, G. Renna, Analysis of corrosion on sintered stainless steel: Mechanical and physical aspects, Eng. Fail. Analy. 95 (2019) 273-282.

[141] M Sugavaneswaran, A.V. Jebaraj, M.D.B. Kumar, K. Lokesh, A.J. Rajan, Enhancement of surface characteristics of direct metal laser sintered stainless steel 316L by shot peening, Surf. Interf. 12 (2018) 31-40, https://doi.org/10.1016/j.surfin.2018.04.010.

[142] C. Barlie, C. Casavola, C. Papalettere, Corrosion effects on mechanical properties of sintered stainless steels, Proc. Struct. Integ. 5 (2017) 195-201.

[143] F. Khodabakhshi, M.H. Farshidianfar, A.P. Gerlich, M. Nosko, V. Trembosov, A. Khajepour, Effects of laser additive manufacturing on microstructure and crystallographic texture of austenitic and martensitic stainless steels, Addit. Manuf. 31 (2020) 100915, https://doi.org/10.1016/j.addma.2019.100915.

[144] A. Reichardt, R.P. Dillon, J.P. Borgonia, A.A. Shapiro, B.W. McEnerney, T. Momose, et al., Development and characterization of Ti-6Al-4V to $304 \mathrm{~L}$ stainless steel gradient components fabricated with laser deposition additive manufacturing, Mater. Des. 104 (2016) 404-413, https://doi.org/10.1016/j.matdes.2016.05.016.

[145] Z. Wang, T.A. Palmer, A.M. Beese, Effect of processing parameters on microstructure and tensile properties of austenitic stainless steel 304L made by directed energy deposition additive manufacturing, Acta Mater. 110 (2016) 226-235.

[146] H. Asgari, M. Mohammadi, Microstructure and mechanical properties of stainless steel CX manufactured by direct metal laser sintering, Mater. Sci. Eng. A 709 (2018) 82-89.

[147] F. Bartolomeu, M. Buciumeanu, E. Pinto, N. Alves, O. Carvalho, F.S. Silva, et al., 316L stainless steel mechanical and tribological behavior - A comparison between selective laser 
melting, hot pressing and conventional casting, Addit. Manuf. 16 (2017) 81-89, http://dx.doi.org/10.1016/j.addma.2017.05.007.

[148] A. Bayode, E.T. Akinlabi, S. Pityana, Microstructure and microhardness of 17-4PH stainless steel made by laser metal deposition, Proc. World Cong. Eng. Comp. Sci. (WCECS), October 19-21, 2016, San Francisco, USA II (2016).

[149] S. Cheruvathur, E.A. Lass, C.E. Campbell, Additive manufacturing of 17-4PH stainless steel: Post-processing heat treatment to achieve uniform reproducible microstructure, JOM, Min. Met. Mater. Soc. 68 (3) (2016) 930-942, https://doi.org/10.1007/s11837-015-1754-4.

[150] K.C. Sanjeev, P.D. Nezhadfar, C. Phillips, M.S. Kennedy, N. Shamsaei, R.L. Jackson, Tribological behavior of $17-4 \mathrm{PH}$ stainless steel fabricated by traditional manufacturing and laser-based additive manufacturing methods, Wear 440-441 (2019) 203100, https://doi.org/10.1016/j.wear.2019.203100.

[151] P. Ponnusamy, S.H. Masood, D. Ruan, S. Palanisamy, R.A.R. Rashid, O.A. Mohamed, Mechanical performance of selective laser melted 17-4PH stainless steel under compressive loading, Solid Freeform Fabrication 2017. Proc. 28th Annual Inter. Solid Freeform Fab. Symp. - An Addit. Manuf. Conf. (2017).

[152] N.S. Mahesha, R. Hanumantharaya, M.B. Davanageri, P. Ramakrishna Devananda, K.M. Shivakumar, Tribological wear behavior of AISI 630 (17-4PH) stainless steel hardened by precipitation hardening, Amer. J. Mater. Sci. 6 (4A) (2016) 6-14.

[153] M. Murayama, Y. Katayama, K. Hono, Microstructural evolution in a 17-4PH stainless steel after aging at $400{ }^{\circ} \mathrm{C}$, Metall. Mater. Trans. A 30 (1999) 345-353.

[154] S. Pasebani, M. Ghayoor, S. Badwe, H. Irrinki, S.V. Atre, Effect of atomizing media and post processing on mechanical properties of 17-4PH stainless steel manufactured via selective laser melting, Addit. Manuf. 22 (2018) 127-137, https://doi.org/10.1016/j.addma.2018.05.011.

[155] P. Ponnusamy, S.H. Masood, S. Palanisamy, R.A. Rahman Rashid, D. Ruan, Characterization of $17-4 \mathrm{PH}$ alloy processed by selective laser melting, Mater. Today Proc. 4 (2017) 8498-8506.

[156] R. Rashid, S.H. Masood, D. Ruan, S. Palanisamy, R.A.R. Rashid, M. Brandt, Effect of scan strategy on density and metallurgical properties of 17-4PH parts printed by Selective Laser Melting (SLM), J. Mater. Proc. Technol. 249 (2017) 502-511, http://dx.doi.org/10.1016/j.jmatprotec.2017.06.023.

[157] R.F. Schaller, J.M. Taylor, J. Rodelas, E.J. Schindelholz, Corrosion properties of powder bed fusion additively manufactured 17-4PH stainless steel, Corrosion 73 (7) (2017) 796-807. 
[158] A. Stashkov, E. Schapova, T. Tsar'kova, E. Sazhina, V. Bychenok, A. Fedorov, A. Kaigorodov, I. Ezhov, Magnetic, electric properties and hardness of 17-4PH stainless steel fabricated by selective laser melting, J. Phys. Conf. Series, 1389 (2019) 012124, https://doi.org/10.1088/1742-6596/1389/1/012124.

[159] A. Yadollahi, N. Shamsaei, S.M. Thompson, A. Elwany, L. Bian, Mechanical and microstructural properties of selective laser melted 17-4PH stainless steel, Proc. ASME 2015, Inter. Mech. Eng. Cong. Exp. (IMECE 2015), Paper No. IMECE2015-52362, USA: Houston, Texas.

[160] A. Gratton, S. Kumpaty, S. Kamara, G. Raju, N. Panda, N. Kanoongo, K. Balasubramanian, Comparison of mechanical, metallurgical properties of 17-4PH stainless steel between direct metal laser sintering (DMLS) and traditional manufacturing methods, Proc. Nat. Conf. Undergrad. Res. (NCUR) 2012, Ogden Utah: Weber State University.

[161] B. AlMangour, J-M. Yang, Improving the surface quality and mechanical properties by shotpeening of 17-4 stainless steel fabricated by additive manufacturing, Mater. Des. 110 (2016) 914-924, https://doi.org/10.1016/j.matdes.2016.08.037.

[162] Z. Hu, H. Zhu, H. Zhang, X. Zeng, Experimental investigation on selective laser melting of 17-4PH stainless steel, Optics Laser Technol. 87 (2017)17-25.

[163] H. Irrinki, T. Harper, S. Badwe, J. Stitzel, O. Gulsoy, G. Gupta, S.V. Atre, Effects of powder characteristics and processing conditions on the corrosion performance of 17-4PH stainless steel fabricated by laser-powder bed fusion, Prog. Addit. Manuf. 3 (2018) 39-49, https://doi.org/10.1007/s40964-018-0048-0.

[164] W.E. Luecke, J.A. Slotwinski, Mechanical properties of austenitic stainless steel made by additive manufacturing, J. Res. Nat. Inst. Stand. Technol. 119 (2014) 398-418, http://dx.doi.org/10.6028/jres.119.015.

[165] L.E. Murr, E. Martinez, J. Hernandez, S. Collins, K.N. Amato, S.M. Gaytan, P.W. Shindo, Microstructures and properties of 17-4PH stainless steel fabricated by selective laser melting, J. Mater. Res. Technol. 1(3) (2012) 167-177.

[166] H.K. Rafi, D. Pal, Nachiket Patil, T.L. Starr, B.E. Stucker, Microstructure and mechanical behavior of 17-4 Precipitation Hardenable Steel processed by Selective laser melting, J. Mater. Eng. Perf. 23 (2014) 4421-4428, https://doi.org/10.1007/s11665-014-1226-y .

[167] M.R. Stoudt, R.E. Ricker, E.A. Lass, L.E. Levine, Influence of postbuild microstructure on the electrochemical behavior of additively manufactured 17-4PH stainless steel, JOM, J. Min. Met. Mater. Soc. 69 (2017) 506-515, https://doi.org/10.1007/s11837-016-2237-y. 
[168] P.D. Nezhadfar, E. Burford, K. Anderson-Wedge, B. Zhang, S. Shao, S.R. Daniewicz, N. Shamsaei, Fatigue crack growth behavior of additively manufactured 17-4PH stainless steel: Effects of build orientation and microstructure, Inter. J. Fatig. 123 (2019) 168-179.

[169] A. Yadollahi , N. Shamsaei, S.M. Thompson, A. Elwany, L. Bian, Effects of building orientation and heat treatment on fatigue behavior of selective laser melted 17-4PH stainless steel, Inter. J. Fatig. 94 (2017) 218-235, http://dx.doi.org/10.1016/j.ijfatigue.2016.03.014.

[170] A.A. Adeyemi, E.T. Akinlabi, R.M. Mahamood, K.O. Sanusi, S. Pityana, M. Tlotleng, Influence of laser power on microstructure of laser metal deposited 17-4PH stainless steel, Mater. Sci. Eng. 225 (2017) 012028, https://doi:10.1088/1757-899X/225/1/012028.

[171] Y. Wu, Q. Guo, W.Lv, F. Huang, The pitting behavior of newly modified 17-4 precipitation hardened stainless steel with different Nb, N and Mo contents, J. Mater. Eng. Perf. 29 (2020) 135-142, https://doi.org/10.1007/s11665-019-04546-6.

[172] L. Ping, C. Qi-zhou, W. Bo-kang, Z. Xian-Zhong, Effect of aging temperature on erosioncorrosion behavior of 17-4PH stainless steels in dilute sulphuric acid slurry, J. Iron Steel Res. Inter. 13 (5) (2006) 73-78, https://doi.org/10.1016/S1006-706X(06)60099-X. 